\title{
Groundwater vulnerability risk assessment in south Darb El Arbaein, south Western Desert
}

\author{
Mohamed ElKashouty ${ }^{1,2}$
}

Received: 5 January 2020 / Accepted: 7 May 2021 / Published online: 15 May 2021

(c) The Author(s) 2021

\begin{abstract}
Groundwater resources in the south Darb El Arbaein are currently threatened by agricultural impact and rock water interaction associated with over exploitation. Planning of Nubian sandstone aquifer is required, especially in this new invest area. It is implemented by GIS to establish vulnerability areas and to evaluate protocol plans for hydrogeological parameters and soil. The TDS concentration ranged from 750 to $1350 \mathrm{ppm}$, confirms the impact of non-point source (agricultural activity). It is because recharging Nile water has TDS concentration of 100-300 ppm. Aquifer vulnerability delineation areas by lithogenic and anthropogenic sources have been recently highlighted for water resources systems planning and management. The correlation among hydrogeological, geological, and hydrogeochemical characteristics was discussed and achieved. Ten stratified beds were matched by GIS with specified average weights to them according to their relative importance for groundwater vulnerability. The chosen layers are TDS, aquitard thickness, water depth, hydraulic conductivity, transmissivity, slope, total hardness (TH), sodium adsorption ratio (SAR), discharge rate (Q), and screen length. The groundwater impact distribution reflect five categories ranged from no to excellent aquifer potential levels. Class I (very low vulnerability) was in the northern part and contains $11.1 \%\left(16.02 \mathrm{~km}^{2}\right)$ of the area. While very high vulnerability (class V) was in southeast, east, it represents $10.4 \%\left(14.96 \mathrm{~km}^{2}\right)$. The preferred invested area was northeast rather than other areas; otherwise, the groundwater degradation enhanced. The vegetation/ or barren lands were established by band 4/band 3, band 3/band 4 ratios and composite RGB 7,4 , and 1 satellite images.
\end{abstract}

Keywords Hydrogeology · Groundwater vulnerability · GIS-RS · South Darb El Arbaein south Western Desert

\section{Introduction}

Determining the pollution influences by infiltration into the aquifer represents the vulnerability establishing. It represents the enhancement sources for aquifer contamination and predicts the aquifer management plan (Prasad and Shukla 2014). Margat (1968) firstly determined the aquifer impact by anthropogenic sources. Rapid urbanization, biological, organic-inorganic pollutants, land application, agricultural, and industrial facility impact on groundwater quality and quantity. Therefore, protection strategies should be taken to manage and control the groundwater.

Mohamed ElKashouty

mohamedkashouty@yahoo.com

1 Department of Hydrogeology, Faculty of Earth Sciences, King Abdulaziz University, Jeddah 21589, Saudi Arabia

2 Faculty of Science, Geology Department, Cairo University, Cairo, Egypt
U.S. Environmental Protection Agency (EPA) established DRASTIC techniques in 1987 in order to capture aquifer contamination rate in the USA (Aller et al. 1987). DRASTIC abbreviated as (D): water depth, (R) net recharge, (A) aquifer media, (S) soil media, (T) topography, (I) impact of the vadose zone, and (C) hydraulic conductivity of the aquifer. DRASTIC match previous parameters to evaluate the aquifer contamination rate (Sahu and Nandi 2015) and define aquifer vulnerability (Knox et al. 1993; Kimand and Hamm 1999; Adamat et al. 2003; Hamza et al. 2007; Leone et al. 2009).

In Drastic modeling, GIS (Nasri et al. 2015), remote sensing (Yeh et al. 2006) and statistical techniques (Burkart et al. 1999; Fred et al. 2002), hydrogeochemistry (Mondal et al. 2017), and fuzzy mathematical method (Zhou et al. 2010) were used to investigate aquifer impact. GIS integrate many information layers into a single one with geo-referencing and spatial analysis. The development in Darb-El-Arbaein was determined by GARPAD (General Authority for Rehabilitation Projects and Agricultural Development) in 1997 
(Fig. 1). Darb-El-Arbaein located in between Egypt and Sudan through Kharga Oasis to Assiut. It is the old line for camel walking from Darfur to Assiut. The groundwater is the only water resources for domestic and irrigation uses; therefore, the aquifer potentiality and vulnerability was the point of interest. About 12,000 feddans were reclaimed and used to construct sixteen buildings for worker housing about $400 \mathrm{~km}$ from Paris village toward southern border. The borehole discharges are in three areas, the northern, the middle, and the southern part of Darb El-Arbaein. The study area (southern part) represent area about $170 \mathrm{~km}^{2}$ (Fig. 1). The area of investigation was high aridity $\left(48.6{ }^{\circ} \mathrm{C}\right.$ in May and $-2{ }^{\circ} \mathrm{C}$ in February). The precipitation was lower than 1.1 $\mathrm{mm} / \mathrm{y}$ with mean of $0.3 \mathrm{~mm} / \mathrm{month}$. The evaporation was $172 \mathrm{~mm} / \mathrm{y}$.

\section{Geomorphology and geologic setting}

Issawi (1971) subdivided the Darb El Arbaein into three zones, the southern Naklai-Sheb peneplain, western Atmur peneplain and plateau. From the geologic point of view, CONOCO map (1989) showed that the exposed rocks ranged from Pre-Cambrian and Quaternary deposits. The stratigraphic setup composed of seven beds, from base to top, Pre-Cambrian basement, Paleozoic-Mesozoic sandstone, Lower Cretaceous, Upper Cretaceous, Paleocene, Eocene, and Quaternary (Table 1) (CONOCO 1989; Fathy et al. 2001; Korany et al. 2002). The Upper Cretaceous overlain the Pre-Cambrian sediments in southern part of Darb El Arbaein (Table 2). The Darb El Arbaein is related structurally to the Red Sea (EGSMA 1987a, 1987b). The up arching of basement sediments established (Fathy et al. 2002).

\section{Hydrogeology}

Eighty wells were drilled in Darb El Arbaein with depths ranging from 130 to $530 \mathrm{~m}$, in 1998 to 2001 . The drilling was done in the successive Nubian sandstone (Paleozoic-Upper Cretaceous). Geological sections show the presence of 18 faults (Fig. 2) (Fathy et al. 2002). The amount of feeding for the aquifer in the Western Desert is about 1.5 billion $\mathrm{m}^{3}$ (Ambroggi 1966). The rate of groundwater migration from Libya to Egypt is about 3.782 million $\mathrm{m}^{3} / \mathrm{y}$ (Ezzat and Abu-Atta 1974). The $\mathrm{C}_{14}$ and $\mathrm{H}_{3}$ isotope studies showed that the life of groundwater is about $1000 \mathrm{BC}$ or earlier (German Water Group 1977). The Nubian aquifer is fossil water (20,000-40,000 y) (Shata et al. 1962; Shata 1982). The Taref Fm. overlain by Kiseiba Fm. (Table 2),

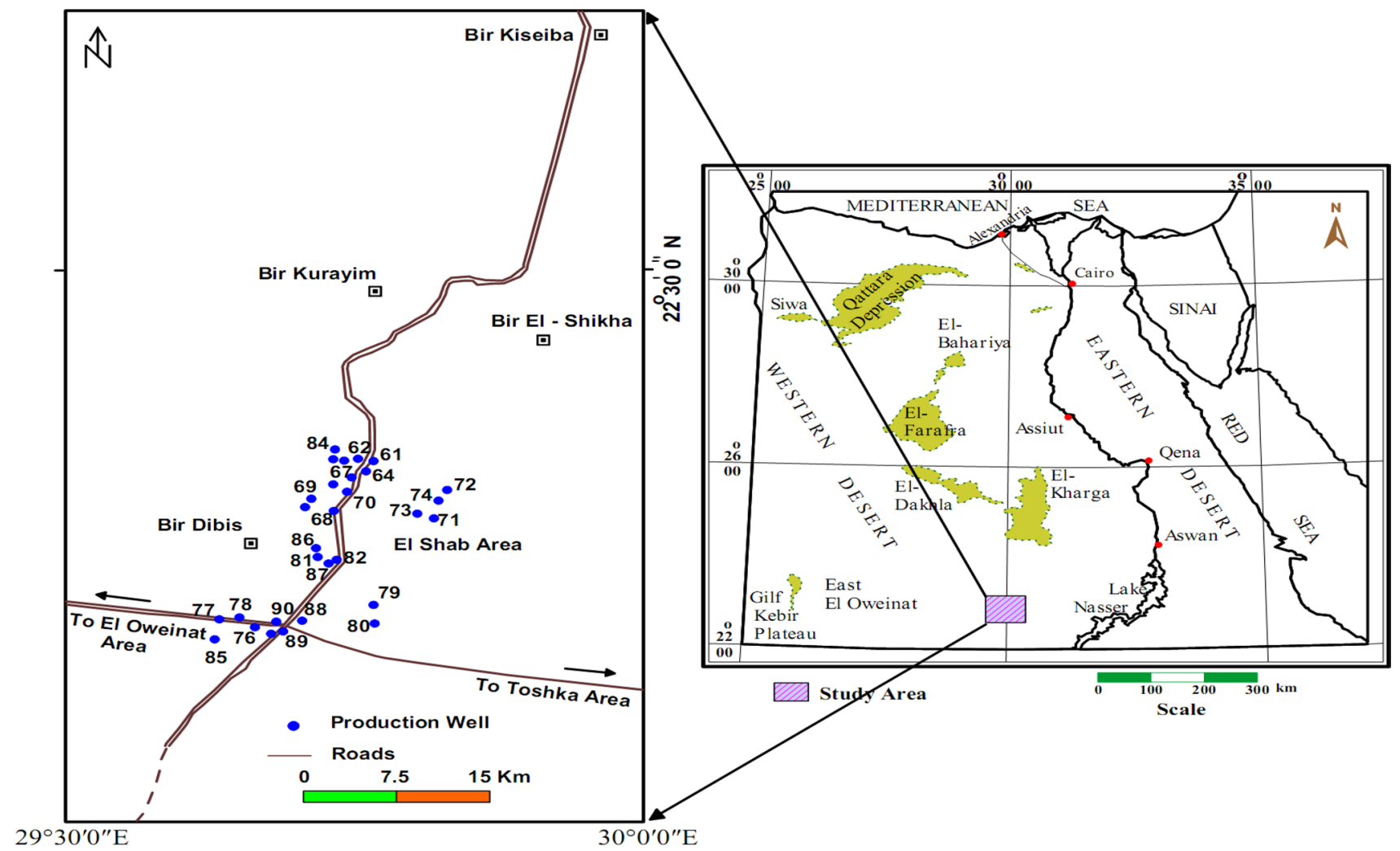

Fig. 1 Base map of the southern Darb El Arbaein 
Table 1 Modified stratigraphic column of Darb El Arbaein (Aggour et al. 2009 and Barseem 2016)

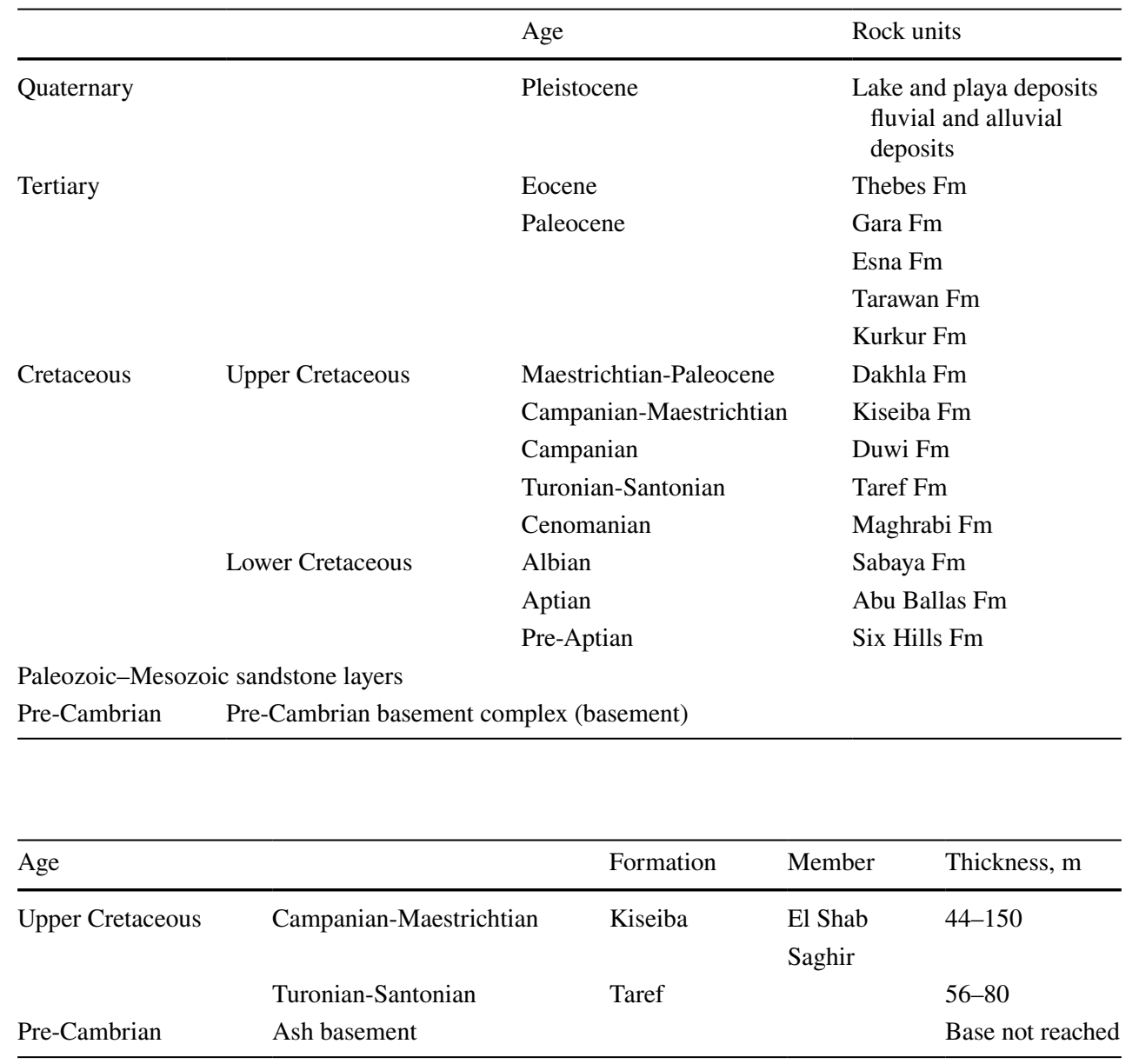

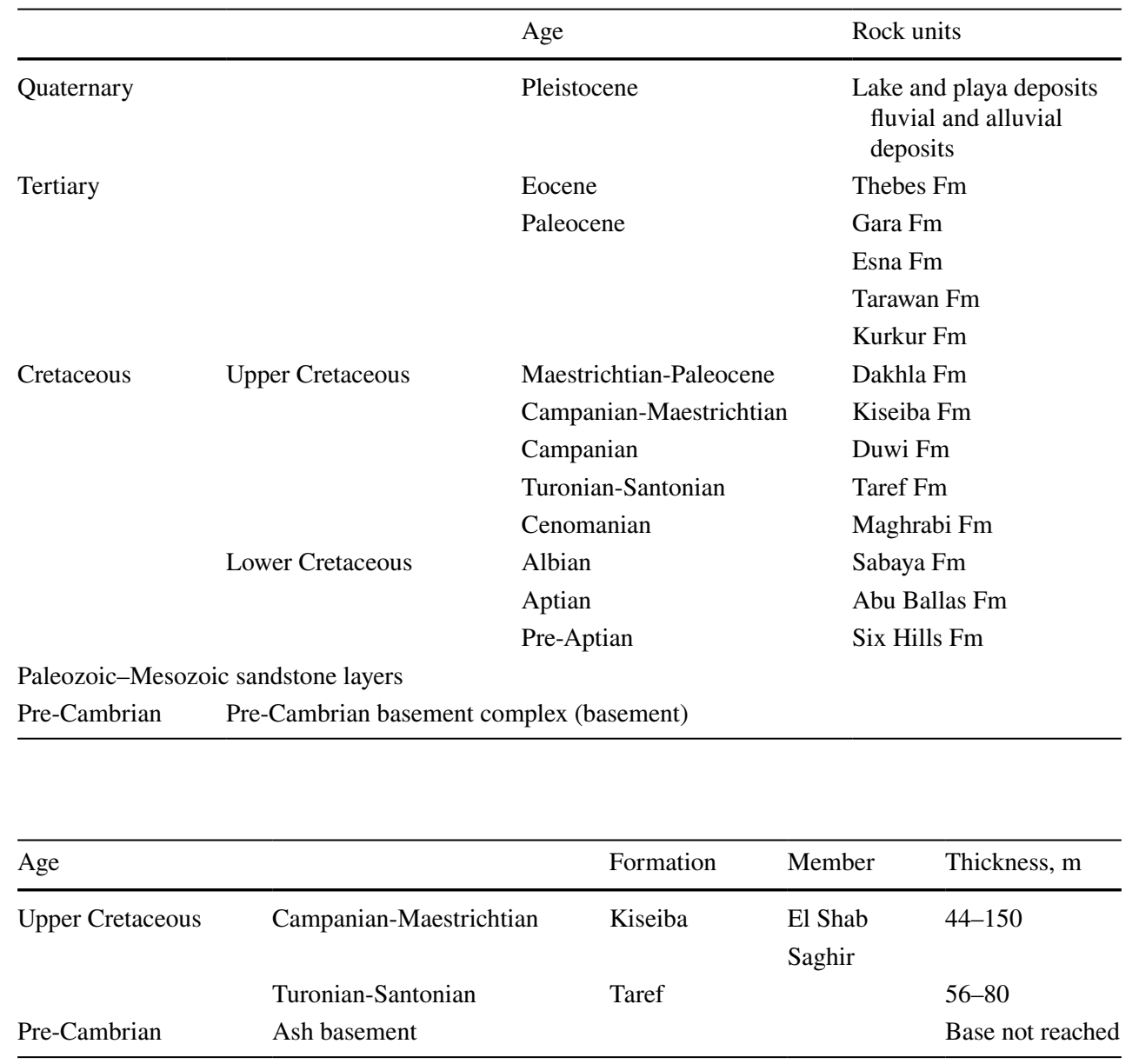

Table 2 Stratigraphic setup in southern Darb El Arbaein (GARPAD et al. 2000) both represent the Nubian aquifer. The top part of Kiseiba Fm. act as aquitard. The aquifer thickness increases in the southwestern and northeastern part (Fig. 3a, b). The lithology consists of coarse-grained sandstone at the bottom that finning upward. It conformably overlies the basement. The Taref Formation (168 m thick) consists of medium to very coarse-grained sandstone with claystone intercalations. The Kiseiba Formation covers most of the surface of Bir El-Shab area. The lower portion of this Formation is called Shagir member, while El-Shab member represents its upper portion (Hendriks et al. 1984). The Kiseiba Formation thickness reaches $144 \mathrm{~m}$ at type locality. It overlies directly Precambrian basement rocks in Bir Kiseiba area and the Taref Formation in Bir El-Shab area (Ghoubashi 2004). The water depth is generally very shallow before pumping (Fig. 4a), which contributed the increase in TDS concentration by evaporation process. After pumping (Fig. 4b), the water depth is much increased, due to low recharge rate. The maximum water depth difference was in the northeast and southeast (Fig. 5a). The latter areas represent the two recharge zones (Fig. 5b), which contributed to groundwater flow into two piezometric lows. The groundwater flow was in the northwestern and central zones (two piezometric lows)
(Fig. 5b). Hydraulic conductivity and transmissivity increase due to southeastern and southwestern part $(9-11 \mathrm{~m} / \mathrm{d}$ and 1277-1491 $\mathrm{m}^{2} / \mathrm{d}$ ), while hydraulic conductivity decreases in the central-northern part $\left(2.4-6 \mathrm{~m} / \mathrm{d}\right.$ and $416-749 \mathrm{~m}^{2} / \mathrm{d}$ and increases again due northwestern part (9-11 m/d), whereas transmissivity declines due the northwestern part (416-749 $\mathrm{m} 2 / \mathrm{d}$ ) (See Figs. 12b and 13a). The decline in transmissivity was attributed to increase in clay concentration (Fathy et al. 2002). The storage coefficient varied from $2.2 * 10^{-4}$ to $3.22 * 10^{-4}$, reflect the confined conditions. The formation loss ranged from $2.36 * 10^{-3}$ to $2.51 * 10^{-3} \mathrm{~d} / \mathrm{m}^{2}$, while well loss varied from $0.93 * 10^{-7}$ to $1.45 * 10^{-7} \mathrm{~d} / \mathrm{m}^{5}$ (Fig. 6a, b). The formation loss decreases due southeastern and northwestern part, more or less coincide with the increases in fines in Nubian aquifer that decline the permeability. The well efficiency at discharge of $150 \mathrm{~m}^{3} / \mathrm{h}$ varied from 84 to $86 \%$ (Fig. 7). Generally, the borehole efficiency is excellent ( $>71 \%$ ), which all are satisfactory for the borehole design application. The losses of wells and formation contributed to drawdowns in boreholes. The estimation equation was:

$\mathrm{S}_{\mathrm{W}}=\mathrm{BQ}+\mathrm{CQ}^{2}$ (Jacob 1946 and Bierschenk 1964) $\mathrm{S}_{\mathrm{w}}$ (drawdown in borehole, $\mathrm{m}$ ), $\mathrm{Q}$ (abstract rate, $\mathrm{m}^{3} / \mathrm{d}$ ), $\mathrm{BQ}$ (loss of formation, i.e., drawdown reflect aquifer

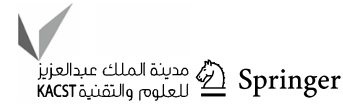



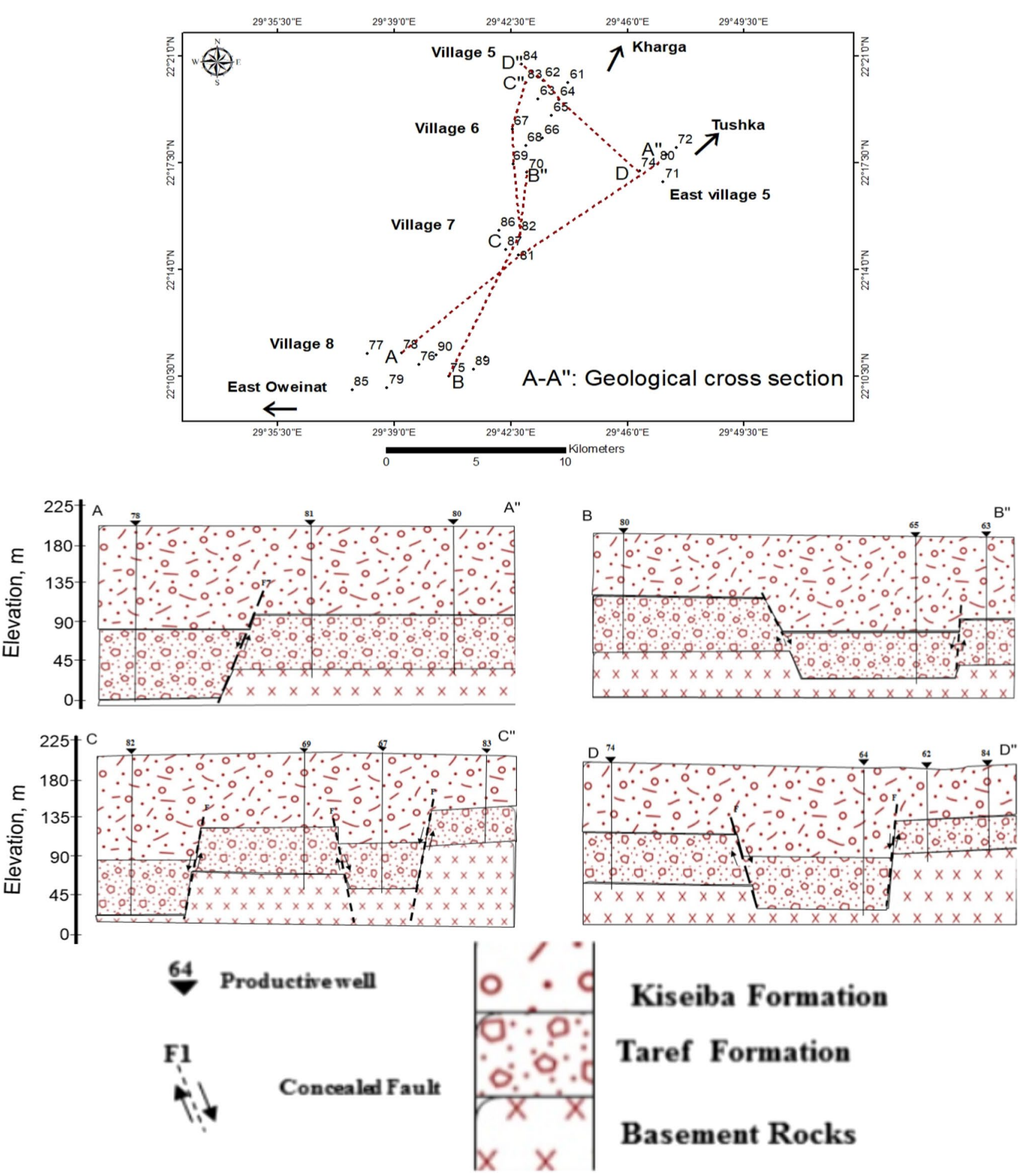

Kiseiba Formation

\section{Taref Formation}

\section{Basement Rocks}

Fig. 2 Geological cross section (modified after Abdel El Rahman 2003)

hydraulic conductivity, $\mathrm{m}$ ), and $\mathrm{CQ}^{2}$ (loss borehole, i.e., drawdown represent hydraulic resistance of borehole screen/ face, $\mathrm{m}$ ). The formation loss relies on geological and hydrogeological conditions, whereas borehole loss based on borehole design and installation such as gravel packing; pipelines screen-casing; screen slotted with respect to slot shape, concentration, number, and size; development; and well depth. If the discharge rate 
Fig. 3 Kiseiba (a) and Taref (b) formation thicknesses
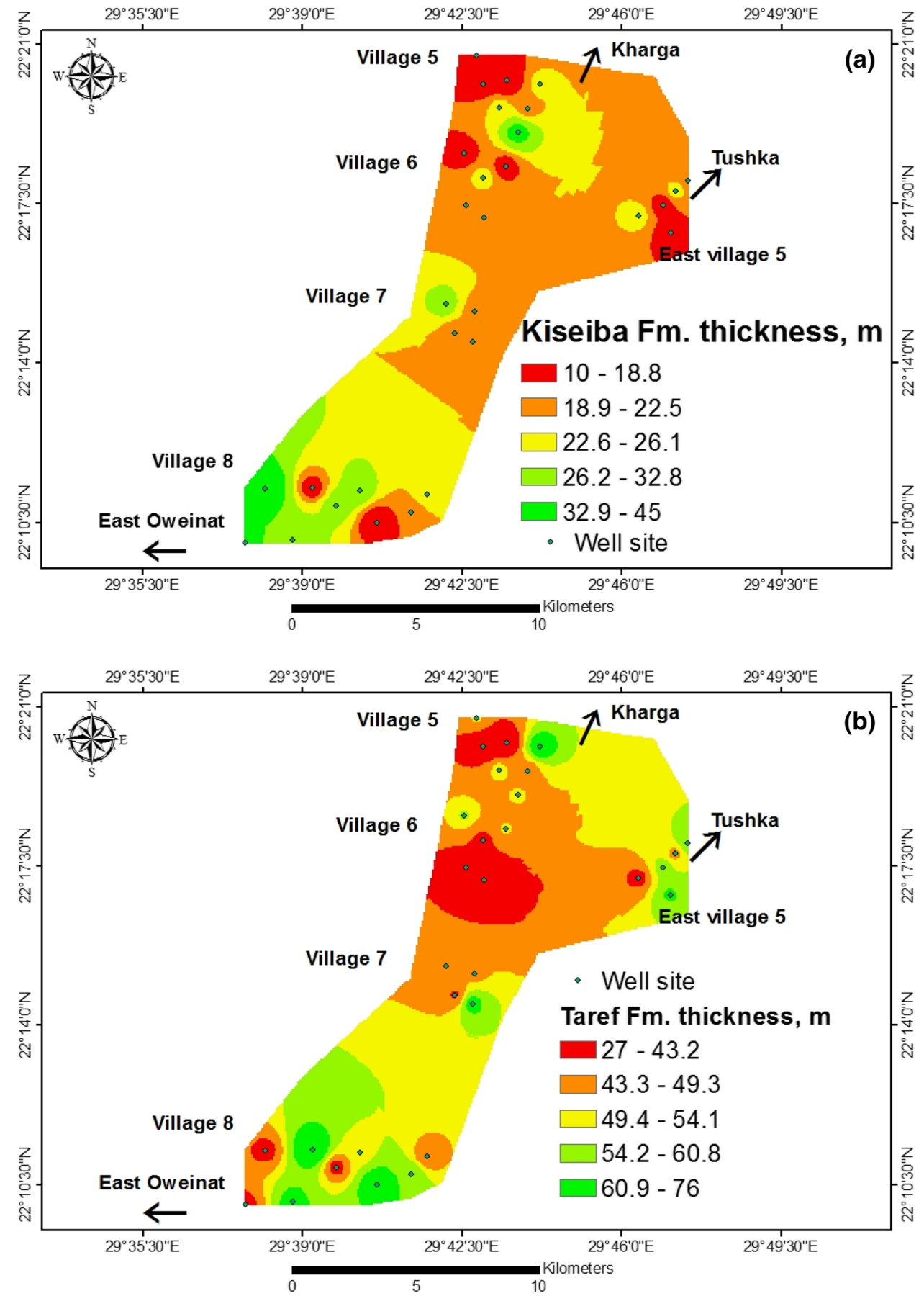

and shale. The elevation ranged from 132 to $213 \mathrm{~m}$ (Fig. 8a, b). The maximum drawdowns was due northeast and southeast, match with maximum formation losses (Fig. 9). The drawdown is mainly attributed to formation loss rather than well loss.
The formation loss coefficient (B) is much higher than well loss coefficient (C) (Fig. 6a, b), reflect a good borehole design and this reflects the excellent well efficiency for all boreholes $(>71 \%)$. The hydraulic conductivity is generally not high $(<12 \mathrm{~m} / \mathrm{d})$ by the alternation of sandstone, clay, increases twice result in decline in borehole efficiency about four times (Jacob 1946).

$\mathrm{S}_{\mathrm{W}} / \mathrm{Q}=\mathrm{B}+\mathrm{CQ}$

well loss.


Fig. 4 Water depths before (a) and after (b) pumping
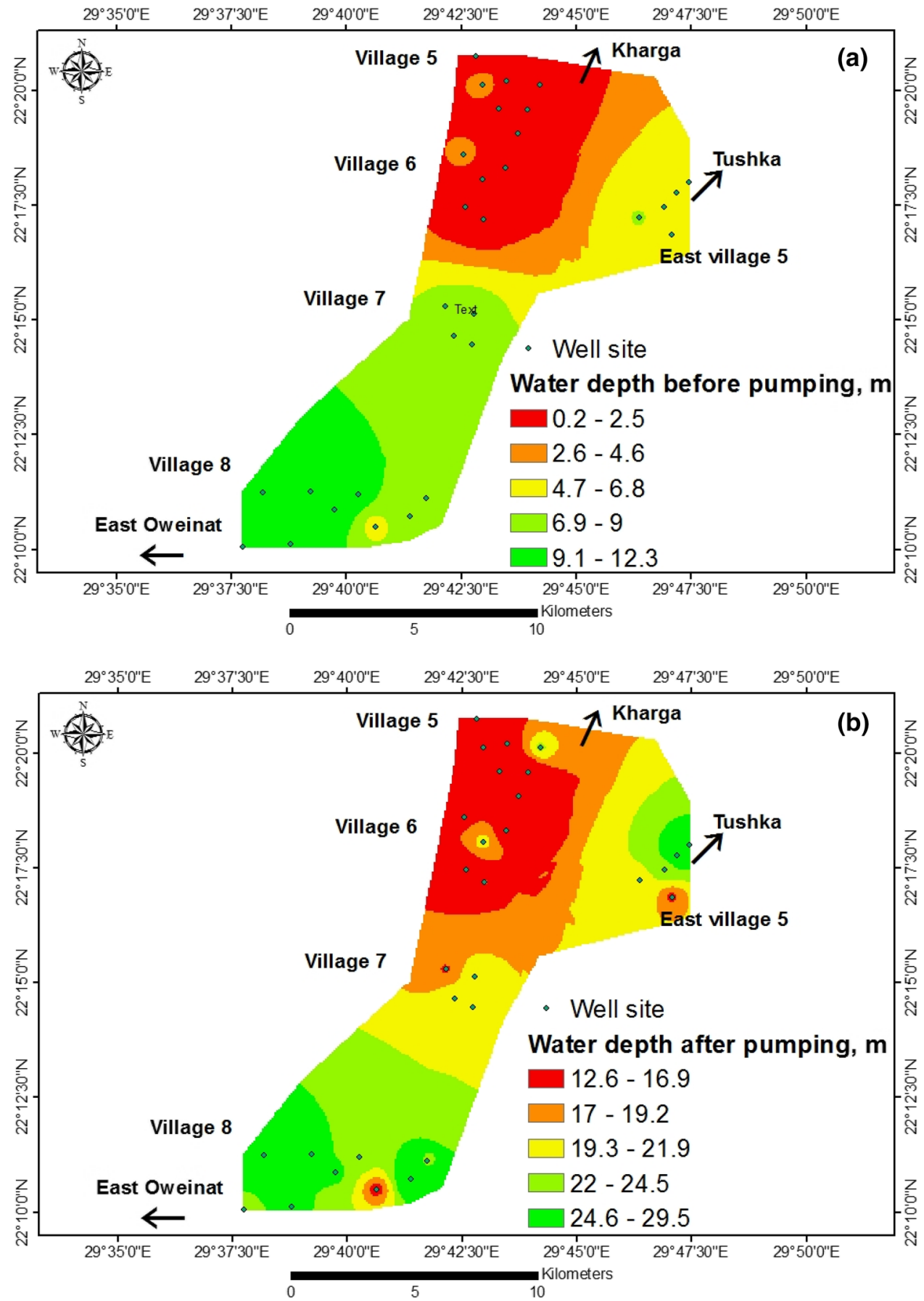

\section{Methodology}

Borehole sites (Fig. 1) digitized by ArcGIS 10.3 package. ArcGIS 10.3 spatial analyst has determined spatial distribution layer for each parameter (TDS, aquitard thickness, water depth, hydraulic conductivity, transmissivity, slope, total hardness $(\mathrm{TH})$, sodium adsorption ratio (SAR), discharge rate $(\mathrm{Q})$, and screen thickness). The "Kriging" techniques were used for areal distribution values. Define the most effective parameters to estimate weights in GIS and multi-criteria decision. Aquifer vulnerability distribution of Nubian sandstone aquifer was constructed. A full flowchart of the techniques was in Fig. 10. The geological, hydrogeological, and hydrogeochemical parameters of the aquifer were collected and distributed by the kriging method. The impact of anthropogenic sources (agriculture), especially in this new investment area, could be evaluated. The hydrogeological and hydrogeochemical interpretation was done by the author. The DRASTIC method was overlay and index category in case of aquifer 
Fig. 5 Water depths differences

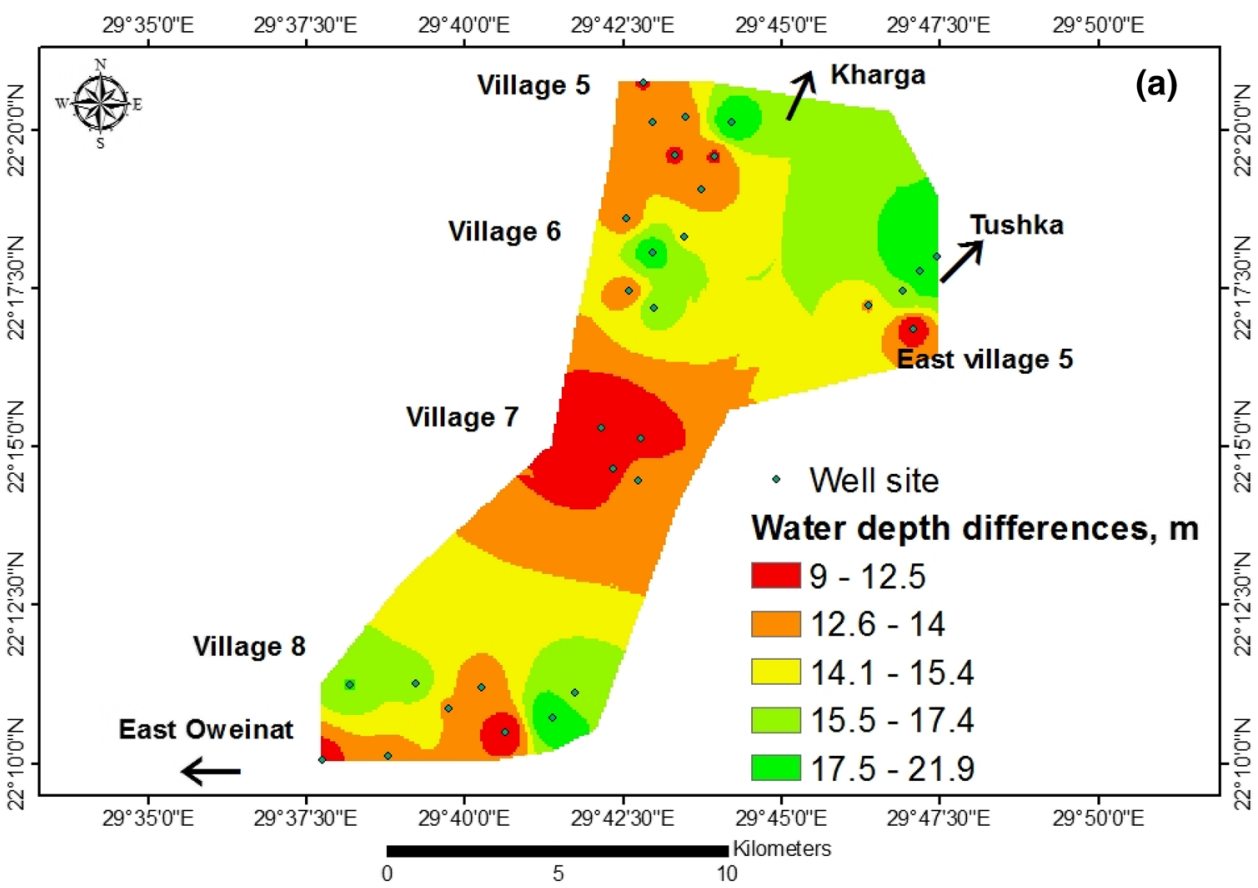

(a) and flow net (b)

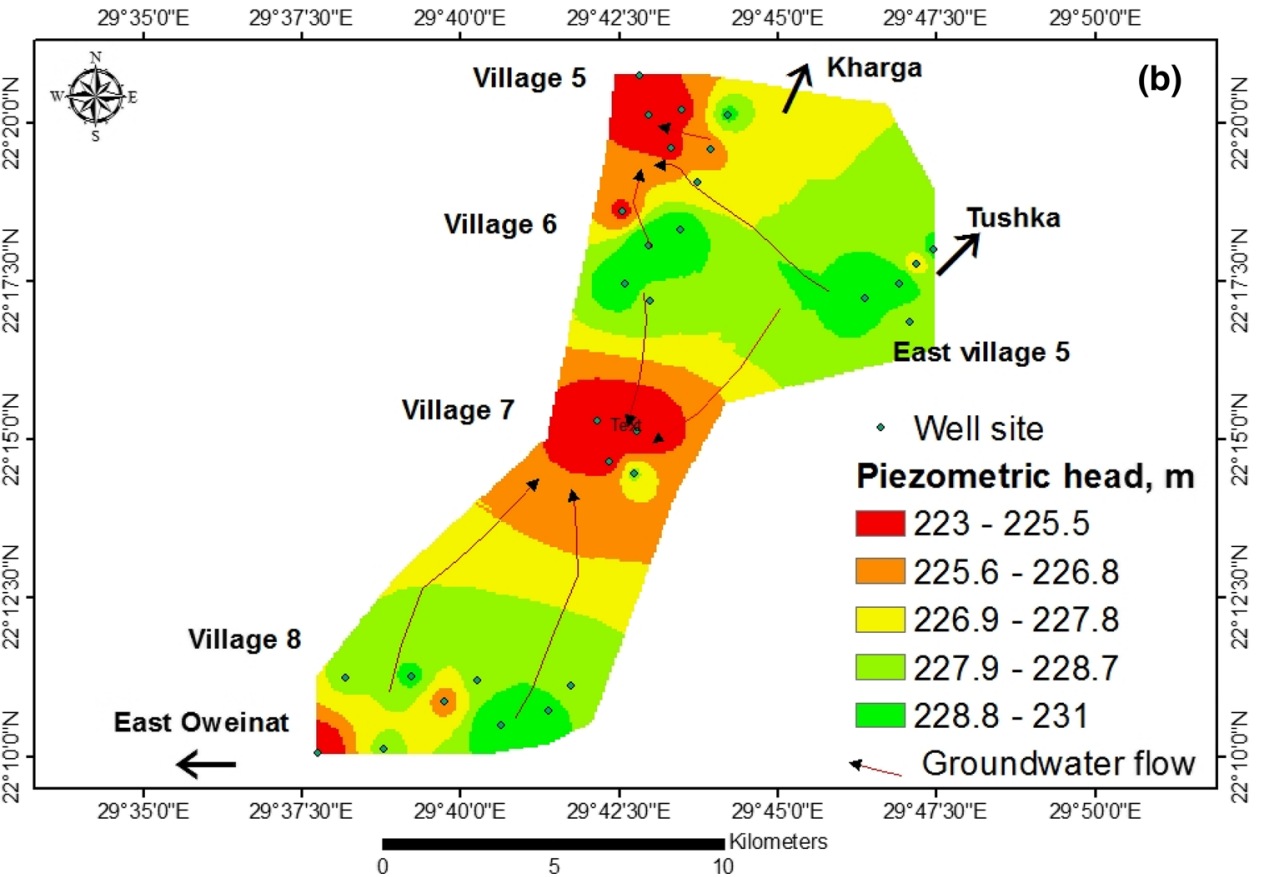

grains (USEPA 1993; Aller et al. 1987). The current dissertation represents a new approach to evaluate groundwater vulnerability by preparation of weighted spatial multi-criteria decision. Thematic maps (ten parameters mentioned previously) were prepared using ArcGIS 10.3. Attribute values are assigned for each and every theme according to classification. Thematic maps reclassified and converted to rasters with common weight scale of $1-5$. The classes were assigned for theme based on aquifer vulnerability from very high to very low vulnerability
(Table 3). The area and percentage of the parameters for each class is determined in Table 3 . The output raster maps were integrated with weighted overlay analysis. The result of overlay analysis (vulnerability map) has been classified into five classes, which ranged from very low to very high aquifer vulnerability. The hydrogeochemical parameters used are total dissolved solids (TDS), total hardness (TH), and sodium adsorption ratio (SAR), while the hydrogeological parameters are aquitard thickness, water depth, hydraulic conductivity, transmissivity, slope, 
Fig. 6 Formation (a) and well (b) losses
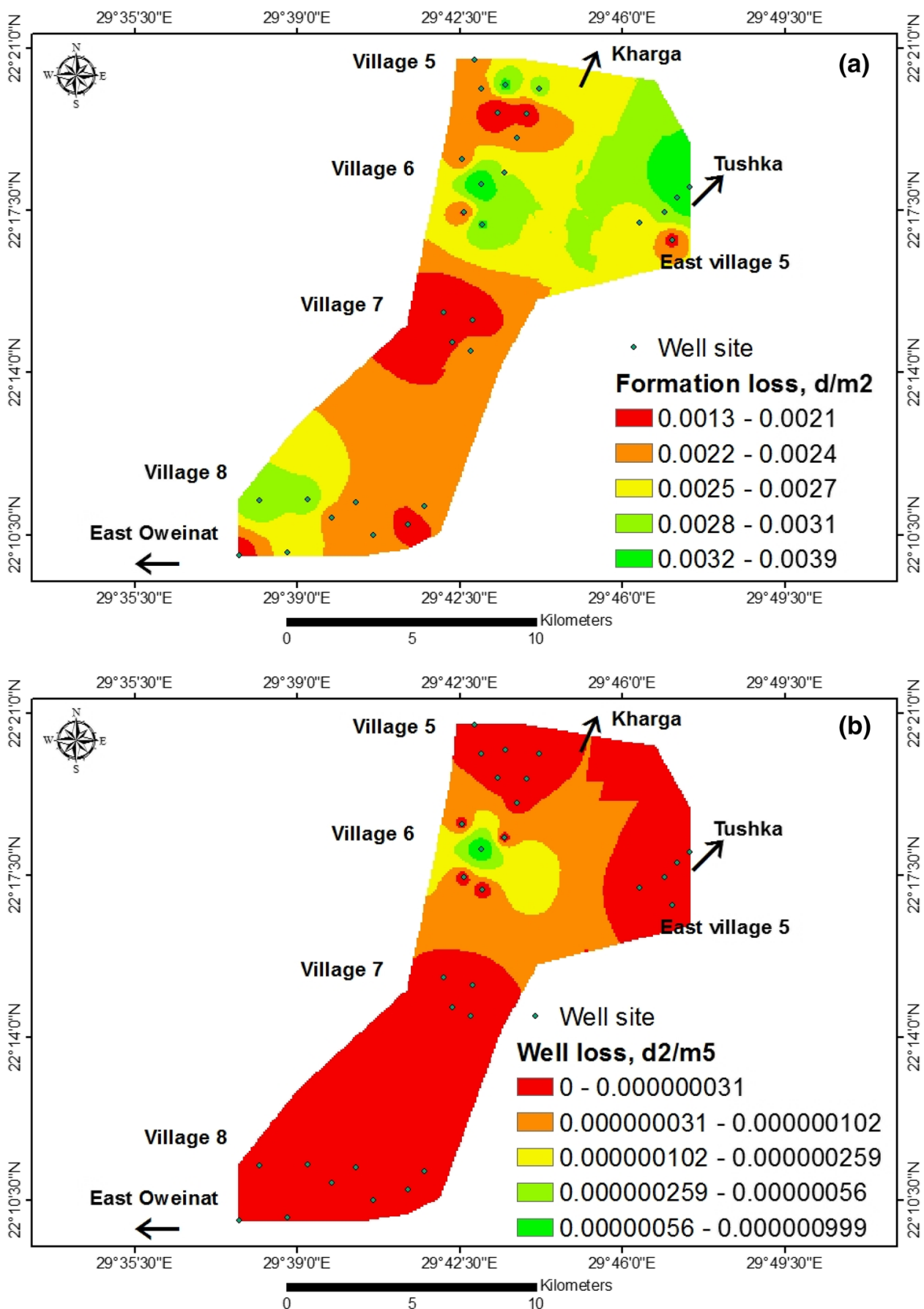

discharge rate (Q), and screen thickness (L). Spatial investigation produces the hydrogeological and hydrogeochemical parameters distribution rasters. It defines the best and worst place for the existence of groundwater in order to give the correct decision to the officials and to maintain the management and non-pollution of the groundwater and not drain it. The digital elevation model (DEM) and Landsat_5 (path/176 and row/045) were acquired from Image courtesy of the U.S. Geological Survey. LANDSAT_SCENE_ID was "LT51760452000036AAA02". The image contains seven bands and no cloud cover (0.00). The available imagery corrected for wavelengths, quick atmospheric, UTM projection WSG84, and contrast stretching. 
Fig. 7 Well efficiency of the aquifer

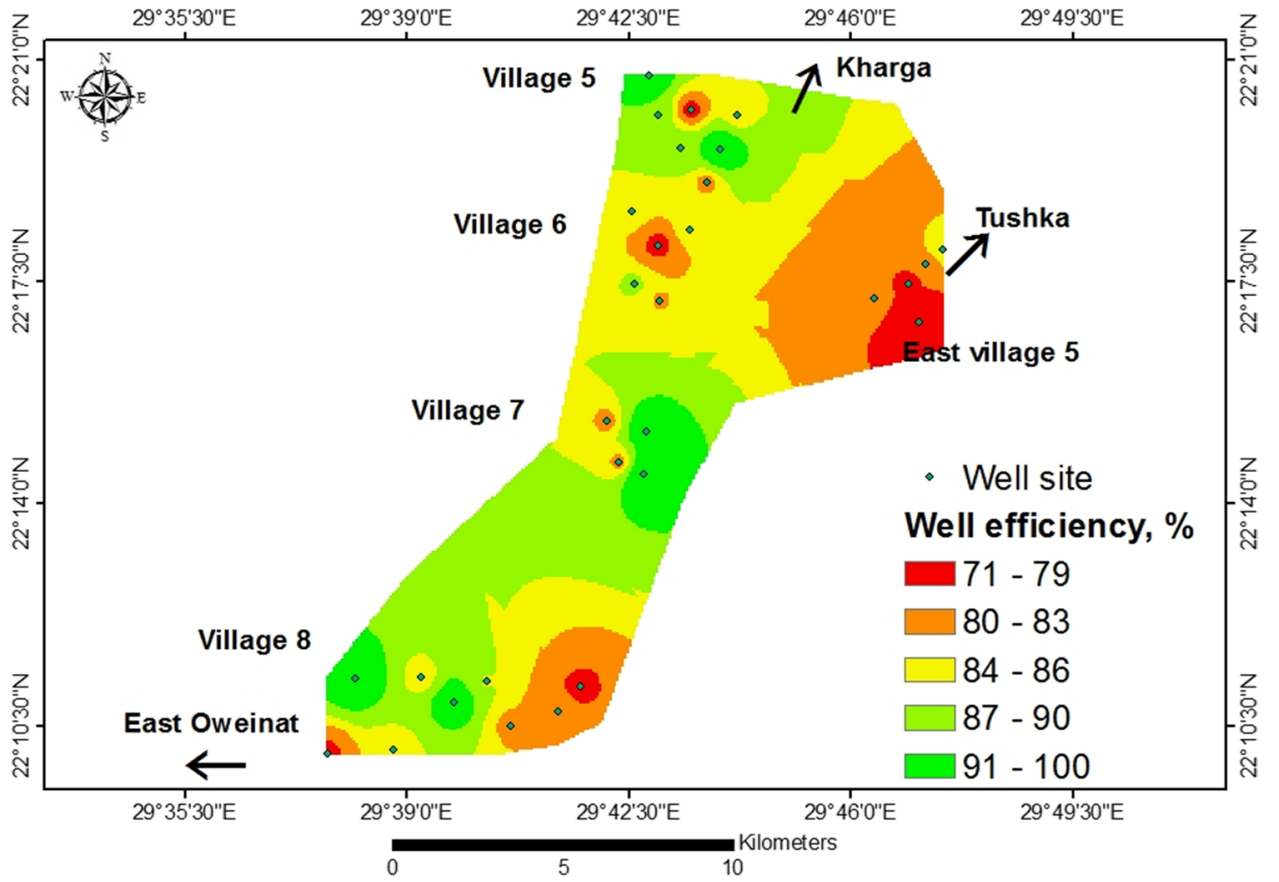

water (Babikeretal 2005). Less aquitard thickness makes groundwater more vulnerable, while high thickness accompanied by less groundwater vulnerability. The aquitard thickness ranges from low (high vulnerable) to high (low vulnerable) (Fig. 11b). The aquitard thickness low to very low vulnerability includes about $21 \%$ of the study area, whereas the high to very high vulnerability represents about $45 \%$ of the study area (Table 3 ). The pollutant dispersion into aquifer depends on water depth (Thirumalaivasan et al. 2003; Brady and Weil 2002). The pollution rate increases in shallower aquifer rather than deeper. The water depth classified into five categories, which ranged from shallow (high pollution rate) to deep (low contamination risk) (Fig. 12a). The water depth high to very high vulnerability showed $34 \%$ of the study area, while low to very low vulnerability represents about $40 \%$ (Table 3).

\section{Hydraulic conductivity and transmissivity}

They increases due southeastern and southwestern part (Figs. 12b and 13a), it is attributed to aquifer thickness increase in these directions. They reflect the contaminants flow into the porous media of the aquifer system. The maximum hydraulic conductivity and transmissivity indicate the highest vulnerability rate. The hydraulic conductivity and transmissivity low to very low vulnerability constitute about 30 and $40 \%$ of the study area, respectively (Table 3). vulnerability). The low to very TDS vulnerability represents about $33 \%$ of the study area, while high to very high vulnerability constitutes $37 \%$ of the area under investigation. (Table 3). The soil textures effect on the infiltrated

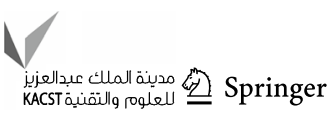


Fig. 8 Elevation (a) and hillshade (b)
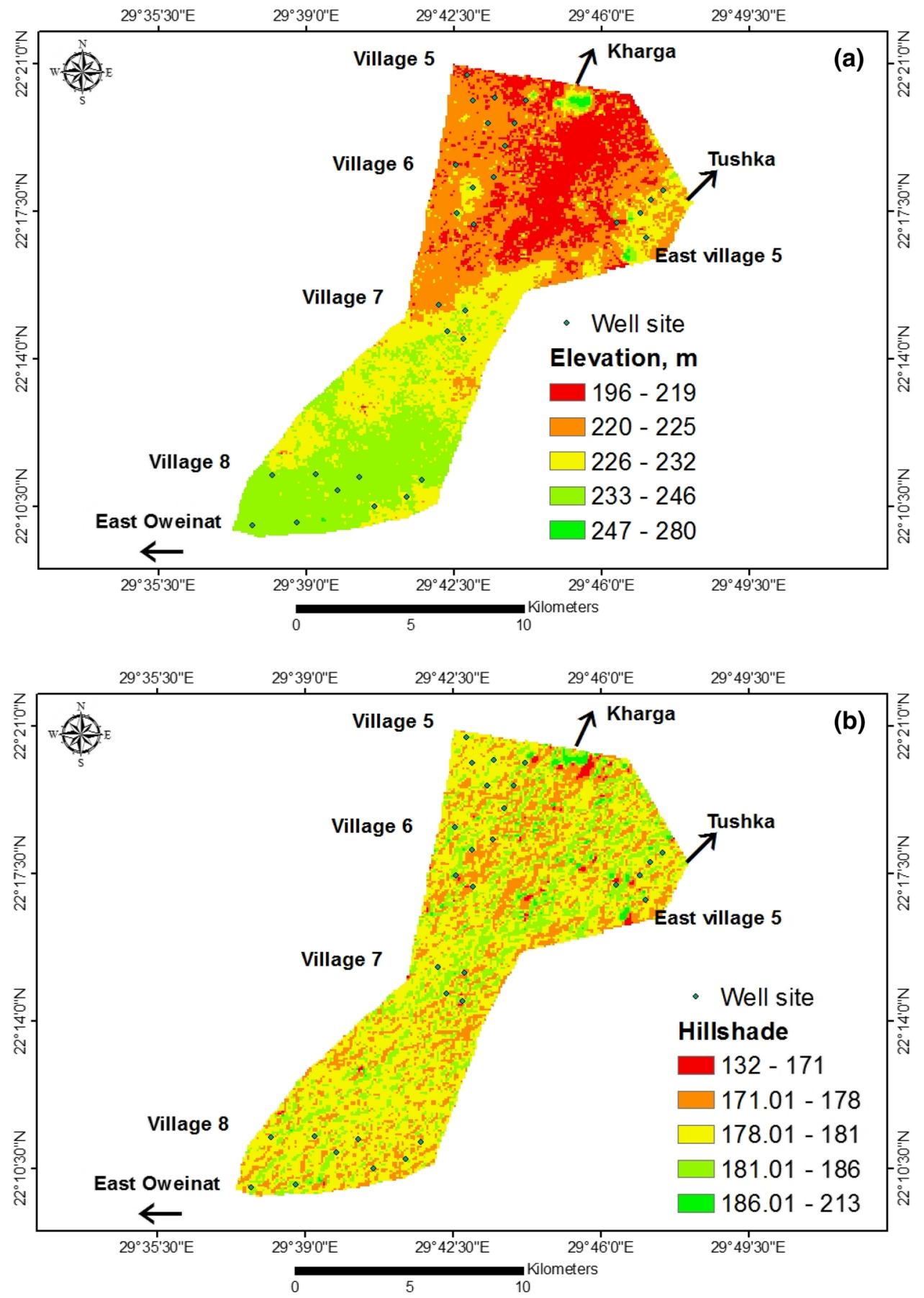

Slope, total hardness $(\mathrm{TH})$, sodium adsorption ratio (SAR)

Earth's surface heights affect the Earth's inclination. The slope rate determines how fast the surface water include dissolved pollutants move. Pollutants in surface water migrate on the earth, leach into groundwater, or settle on the ground. Surface water from agricultural drainage is carried out on different inclinations where the lowest slope is more leaching of pollutants into groundwater (much vulnerable). The slope was estimated from the DEM data and ranged from 0 to 15 degrees (Fig. 13b) with the highest vulnerability grade (5) corresponding to gentle slopes. The total hardness (TH) ranged from 260 to 420 as $\mathrm{CaCO}_{3}$ with five grades 1 (low $\mathrm{TH}$ ) to 5 (high TH and max. vulnerability) (Fig. 14a). TH is mainly contributed by both $\mathrm{Ca}$ and $\mathrm{Mg}$ ions from anthropogenic and lithogenic sources. Total dissolved solids (TDS) and $\mathrm{Na}+\mathrm{K} / \mathrm{Ca}+\mathrm{Mg}$ ratio determine the water quality levels (Ayers and Westcot 1985). SAR ranged from 4 (northwest and southwest) to 7.5 (northeast and southeast) (Fig. 14b). It grades into five classes 1 to 5 of maximum SAR and highest 
Fig. 9 Drawdown of the aquifer
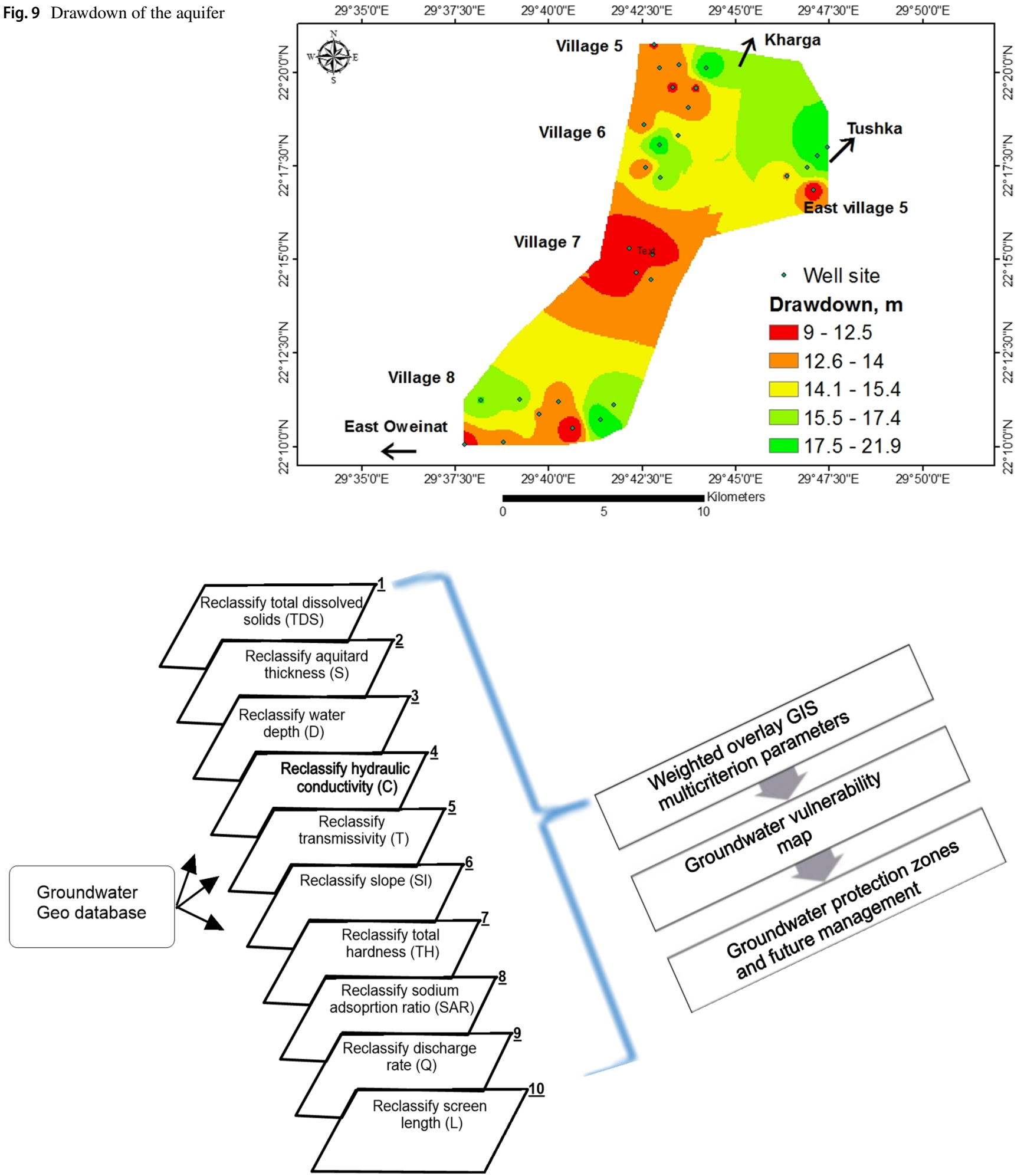

Fig. 10 Flowchart of model methodology 
Table 3 Contribution parameters for aquifer vulnerability distribution

\begin{tabular}{|c|c|c|c|c|c|c|c|}
\hline Thematic layer & Map weight (wt.) & Class ranges & Degree & Rank & $\begin{array}{l}\text { Capability } \\
\text { value }(\mathrm{CV} .)\end{array}$ & Area $(\mathrm{km} 2)$ & Area $(\%)$ \\
\hline \multirow[t]{5}{*}{$1-\mathrm{TDS}, \mathrm{ppm}$} & \multirow{5}{*}{$20 \%(0.2)$} & $736-923$ & Very low & 1 & 0.07 & 13.59 & 9.38 \\
\hline & & 924-1019 & & 2 & 0.13 & 34.50 & 23.81 \\
\hline & & $1020-1117$ & & 3 & 0.20 & 41.41 & 28.58 \\
\hline & & $1118-1213$ & & 4 & 0.27 & 44.59 & 30.77 \\
\hline & & $1214-1318$ & Very high & 5 & 0.33 & 10.81 & 7.46 \\
\hline \multirow[t]{5}{*}{ 2- Aquitard thickness, m } & \multirow{5}{*}{$15 \%(0.15)$} & $30-40.6$ & Very high & 5 & 0.33 & 22.79 & 15.73 \\
\hline & & $40.7-46.4$ & & 4 & 0.27 & 42.28 & 29.18 \\
\hline & & $46.5-51.1$ & & 3 & 0.20 & 48.76 & 33.65 \\
\hline & & $51.2-56$ & & 2 & 0.13 & 21.05 & 14.53 \\
\hline & & $56.1-63$ & Very low & 1 & 0.07 & 10.01 & 6.91 \\
\hline \multirow[t]{5}{*}{$3-$ water depth, m } & \multirow{5}{*}{$10 \%(0.1)$} & $12.6-16.9$ & Very high & 5 & 0.33 & 18.84 & 13.01 \\
\hline & & $17-19.2$ & & 4 & 0.27 & 30.43 & $\mathrm{f} 21.00$ \\
\hline & & $19.3-21.9$ & & 3 & 0.20 & 37.40 & 25.81 \\
\hline & & $22-24.5$ & & 2 & 0.13 & 28.60 & 19.74 \\
\hline & & $24.6-29.5$ & Very low & 1 & 0.07 & 29.61 & 20.44 \\
\hline \multirow[t]{5}{*}{ 4- Hydraulic conductivity, m/d } & & $2.4-6$ & Very low & 1 & 0.07 & 5.60 & 3.87 \\
\hline & & $6.1-7.1$ & & 2 & 0.13 & 37.71 & 26.03 \\
\hline & $10 \%(0.1)$ & $7.2-8$ & & 3 & 0.20 & 32.12 & 22.17 \\
\hline & & $8.1-9$ & & 4 & 0.27 & 52.73 & 36.40 \\
\hline & & $9.1-11$ & Very high & 5 & 0.33 & 16.71 & 11.53 \\
\hline \multirow[t]{5}{*}{ 5- Transmissivity, $\mathrm{m} 2 / \mathrm{d}$} & & $416-749$ & Very low & 1 & 0.07 & 24.60 & 16.98 \\
\hline & & $750-935$ & & 2 & 0.13 & 35.17 & 24.27 \\
\hline & $10 \%(0.1)$ & $936-1116$ & & 3 & 0.20 & 30.85 & 21.29 \\
\hline & & $1117-1276$ & & 4 & 0.27 & 42.92 & 29.62 \\
\hline & & $1277-1491$ & Very high & 5 & 0.33 & 11.37 & 7.84 \\
\hline \multirow[t]{5}{*}{ 6- Slope, degree } & & $0-0.7$ & Very high & 5 & 0.33 & 0.327 & 0.22 \\
\hline & & $0.8-1.7$ & & 4 & 0.27 & 2.019 & 1.34 \\
\hline & $10 \%(0.1)$ & $1.8-3.6$ & & 3 & 0.20 & 10.431 & 6.93 \\
\hline & & $3.7-7.3$ & & 2 & 0.13 & 59.867 & 39.78 \\
\hline & & $7.4-14.6$ & Very low & 1 & 0.07 & 77.845 & 51.73 \\
\hline \multirow[t]{5}{*}{ 7- Total hardness (CaCO3) } & & $260-301$ & Very low & 1 & 0.07 & 11.42 & 10.14 \\
\hline & $5 \%(0.05)$ & $302-323$ & & 2 & 0.13 & 33.37 & 29.62 \\
\hline & & $324-343$ & & 3 & 0.20 & 34.66 & 30.77 \\
\hline & & $344-360$ & & 4 & 0.27 & 33.21 & 29.48 \\
\hline & & $361-420$ & Very high & 5 & 0.33 & 32.23 & 28.61 \\
\hline \multirow[t]{5}{*}{ 8- Sodium adsorption ratio (SAR) } & & $4.1-5$ & Very low & 1 & 0.07 & 16.58 & 11.44 \\
\hline & & $5.1-5.4$ & & 2 & 0.13 & 39.67 & 27.38 \\
\hline & $5 \%(0.05)$ & $5.5-5.8$ & & 3 & 0.20 & 37.98 & 26.21 \\
\hline & & $5.9-6.4$ & & 4 & 0.27 & 39.52 & 27.28 \\
\hline & & $6.5-7.3$ & Very high & 5 & 0.33 & 11.13 & 7.68 \\
\hline \multirow[t]{5}{*}{ 9- Pumping rate, $\mathrm{m} 3 / \mathrm{h}$} & & $60-122$ & Very low & 1 & 0.07 & 2.53 & 1.75 \\
\hline & & $123-167$ & & 2 & 0.13 & 4.01 & 2.76 \\
\hline & $10 \%(0.1)$ & $168-199$ & & 3 & 0.20 & 17.03 & 11.75 \\
\hline & & $200-212$ & & 4 & 0.27 & 33.11 & 22.84 \\
\hline & & $213-220$ & Very high & 5 & 0.33 & 88.28 & 60.90 \\
\hline
\end{tabular}


Table 3 (continued)

Thematic layer

Map weight (wt.)

Class ranges

Degree

Rank

Capability value (CV.)

10- Screen length, $\mathrm{m}$

$42-71$
$72-88$

$\begin{array}{ll}42-71 & \text { Very low } \\ 72-88 & \end{array}$

10.07

0.07

0.13

4.28

2.95

$5 \%(0.05)$

89-100

3

0.20

36.59

25.26

101-123

4

0.27

32.25

22.26

124-172

Very high

5

0.33

70.48

48.64

1.29

0.89

Fig. 11 TDS (a) and aquitard thickness (b) reclassify
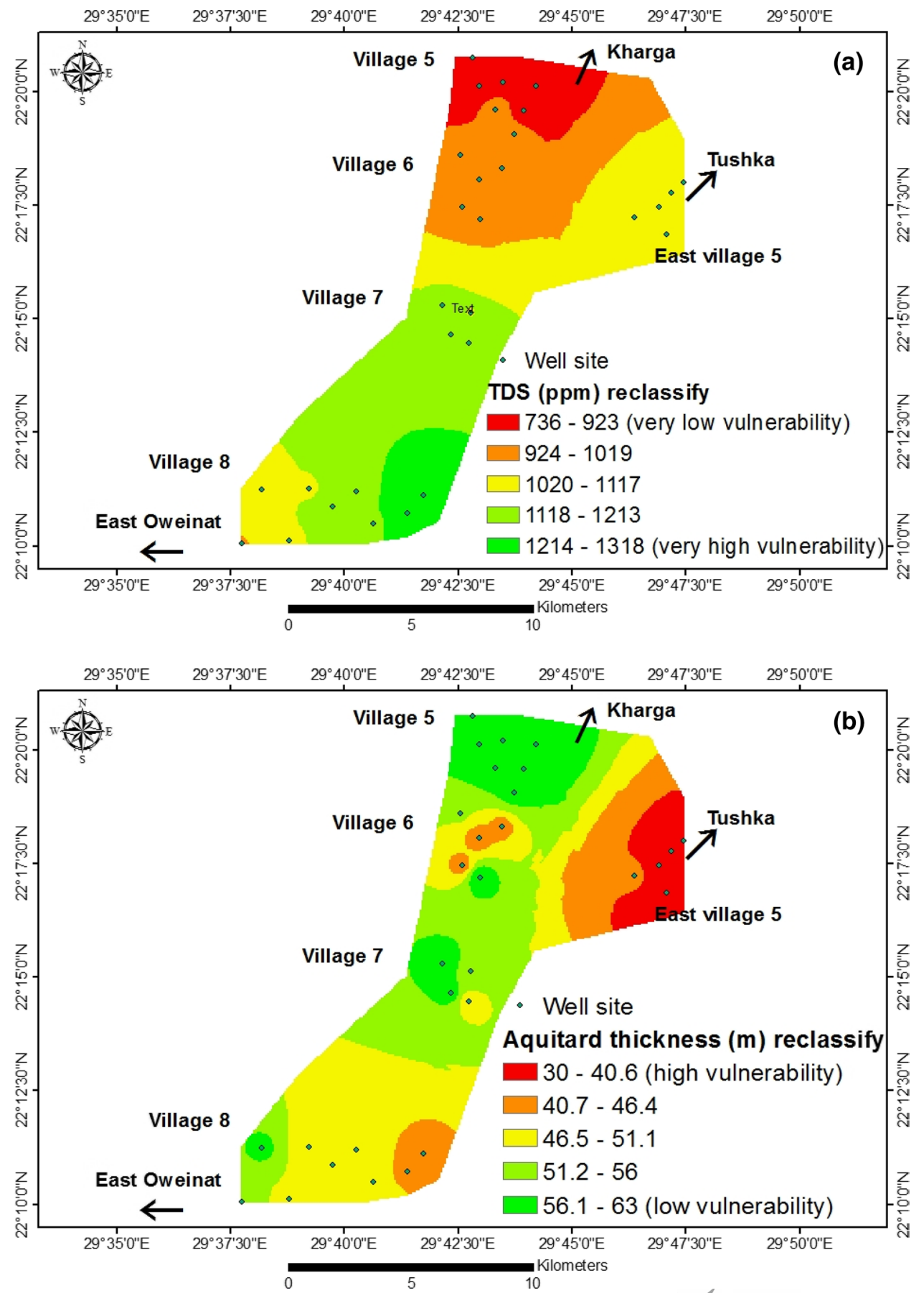
Fig. 12 Water depth (a) and hydraulic conductivity (b) reclassify
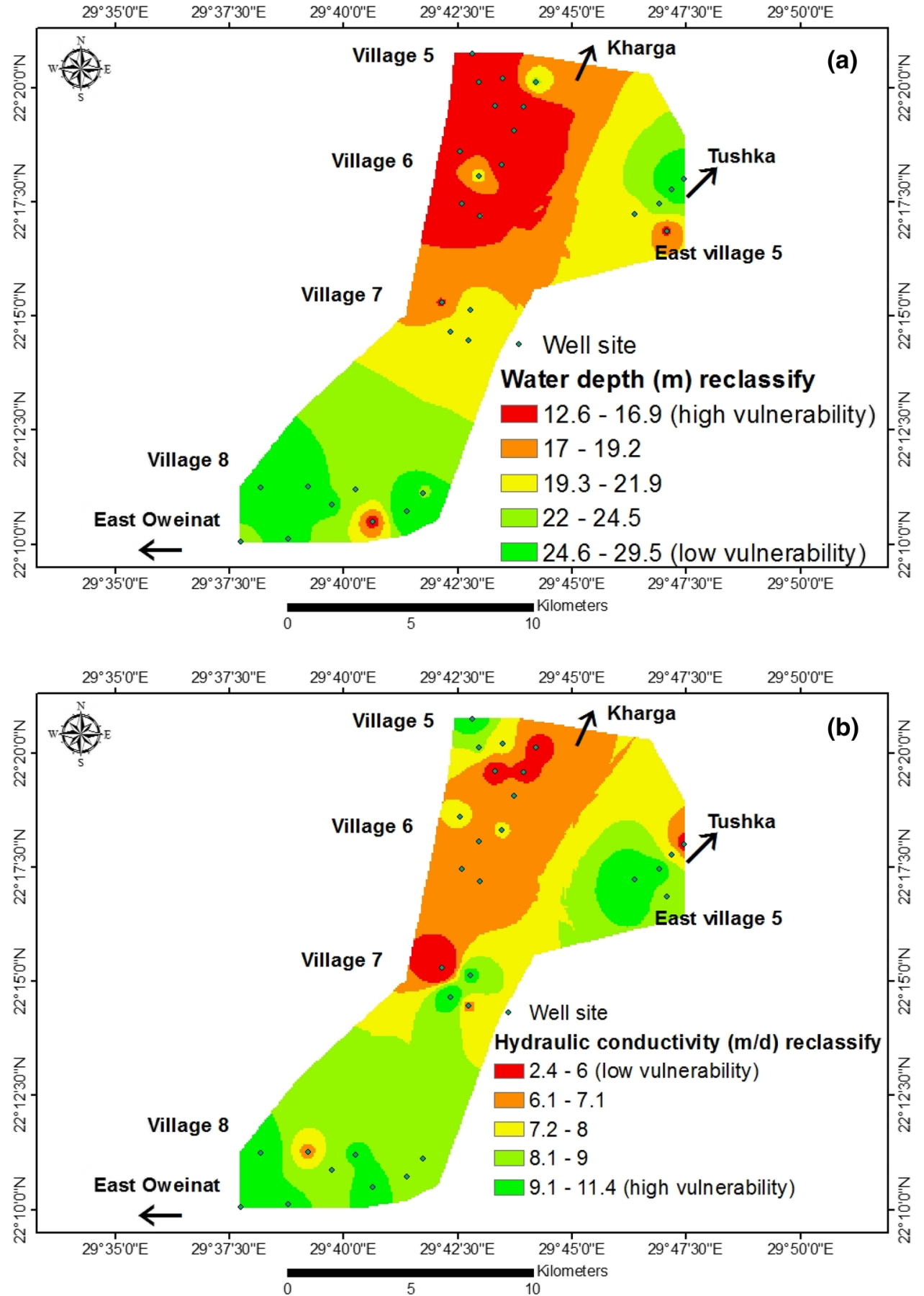

vulnerability. The slope, TH, and SAR low to very low vulnerability represents about 91,39 , and $38 \%$ of the study area, respectively (Table 3), while high to very high vulnerability indicates about $1.5,58$, and $35 \%$ of the investigation area, respectively (Table 3 ).

\section{Discharge rate $(\mathrm{Q})$ and screen thickness}

Agricultural drainage depends on the amount of water extracted from the non-renewable aquifer (current case) in the dry areas, and this increases the salinity of the aquifer. The Q increases due south and east (Fig. 15a) to reach $220 \mathrm{~m}^{3} / \mathrm{h}$. The maximum discharge area coincides with the highest potentiometric surface, reflects upward flow of deep fresh groundwater. The screen length ranged from 42 to $172 \mathrm{~m}$ (Fig. 15b), with maximum vulnerability in highest lengths. The $\mathrm{Q}$ and screen length low to very low vulnerability constitutes 4 and $28 \%$, respectively (Table 3 ), while high to very high vulnerability indicates about 38 and $49 \%$ of the investigation area, respectively (Table 3 ). 
Fig. 13 Transmissivity (a) and slope (b) reclassify
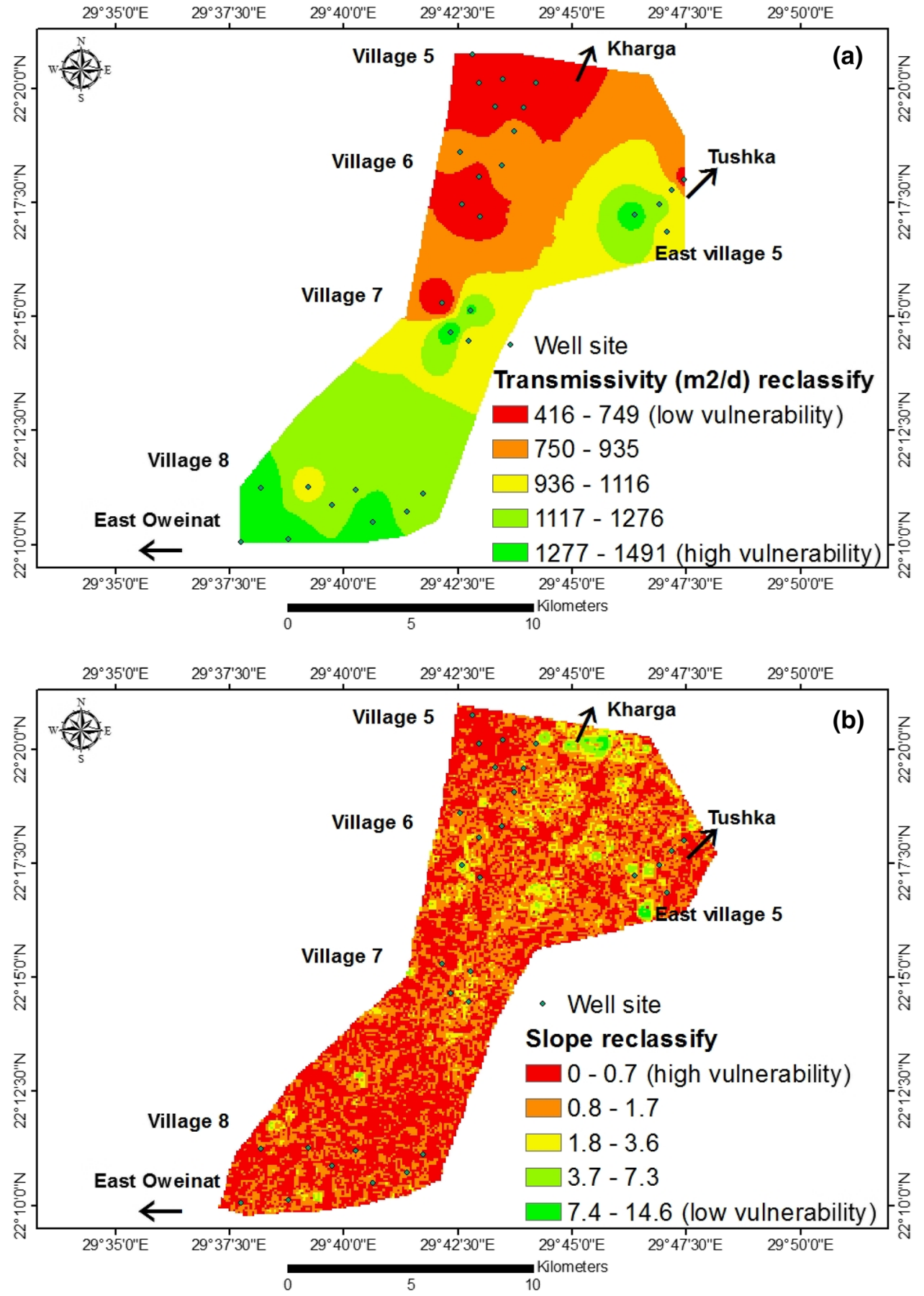

\section{The vulnerability map}

The aquifer vulnerability map was extracted from different geological, hydrogeological, and hydrogeochemical thematic maps, and it is very important for aquifer management, recharge, and protection. Each parameter map was given the weights, which is based on the contribution for groundwater pollution (Table 3). These thematic maps were integrated by GIS model to predict the promising map (aquifer vulnerability). The rank of each class was divided by the total summation values of the layer classes to calculate the capability values (CV.) (Table 3 ). These capability values (CV.) are multiplied by the respective probability layer weight in each thematic layer to calculate the groundwater vulnerability map (Fig. 12). The latter was mathematically calculated using ARC GIS raster calculator analysis as follows:

$\mathrm{GWV}=\sum \mathrm{Wt} . * \mathrm{CV}$ 
Fig. 14 Total hardness (a) and SAR (b) reclassify
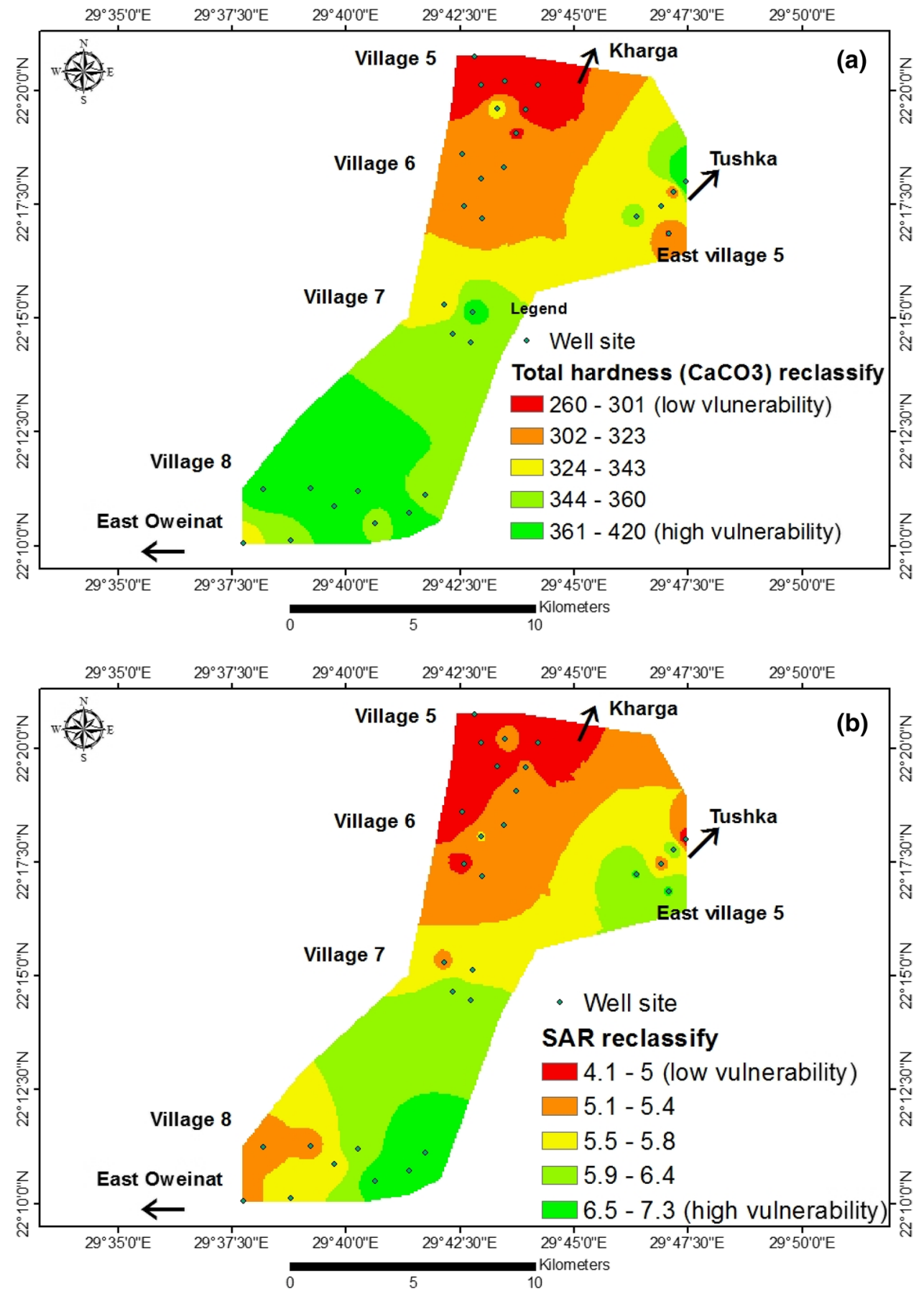

GWV is groundwater vulnerability, Wt is map weight, and $\mathrm{CV}$ is capability value.

GWV $=\sum$ TDS, aquitard thickness, water depth, hydraulic conductivity, transmissivity, slope, total hardness (TH), sodium adsorption ratio (SAR), discharge rate (Q), and screen thickness.

The TDS parameter has the highest contribution in aquifer salinization. The River Nile (TDS $<200$ ppm) recharge the groundwater; TDS concentration of the aquifer degraded with time to reach the current contents (Fig. 11a). The discharge rate influences indirectly the vulnerability evaluation, by overpumping, result in agricultural wastewater leakage and much more rock (soil) water interaction. Five units indicate aquifer vulnerability rate (Fig. 16). Class I (low vulnerability) was in the northwestern part while the high vulnerability (class V) was in the southeast and east (Fig. 16). The output groundwater degradation (vulnerability) map covers area $52.18 \mathrm{~km}^{2}$, represents $36.12 \%$ for low to very low vulnerability level (Table 4). The moderate, high, and very high vulnerability levels are $18.95,34.58$, and $10.34 \%$, 
Fig. 15 Pumping rate (a) and screen length $(\mathbf{b})$ reclassify
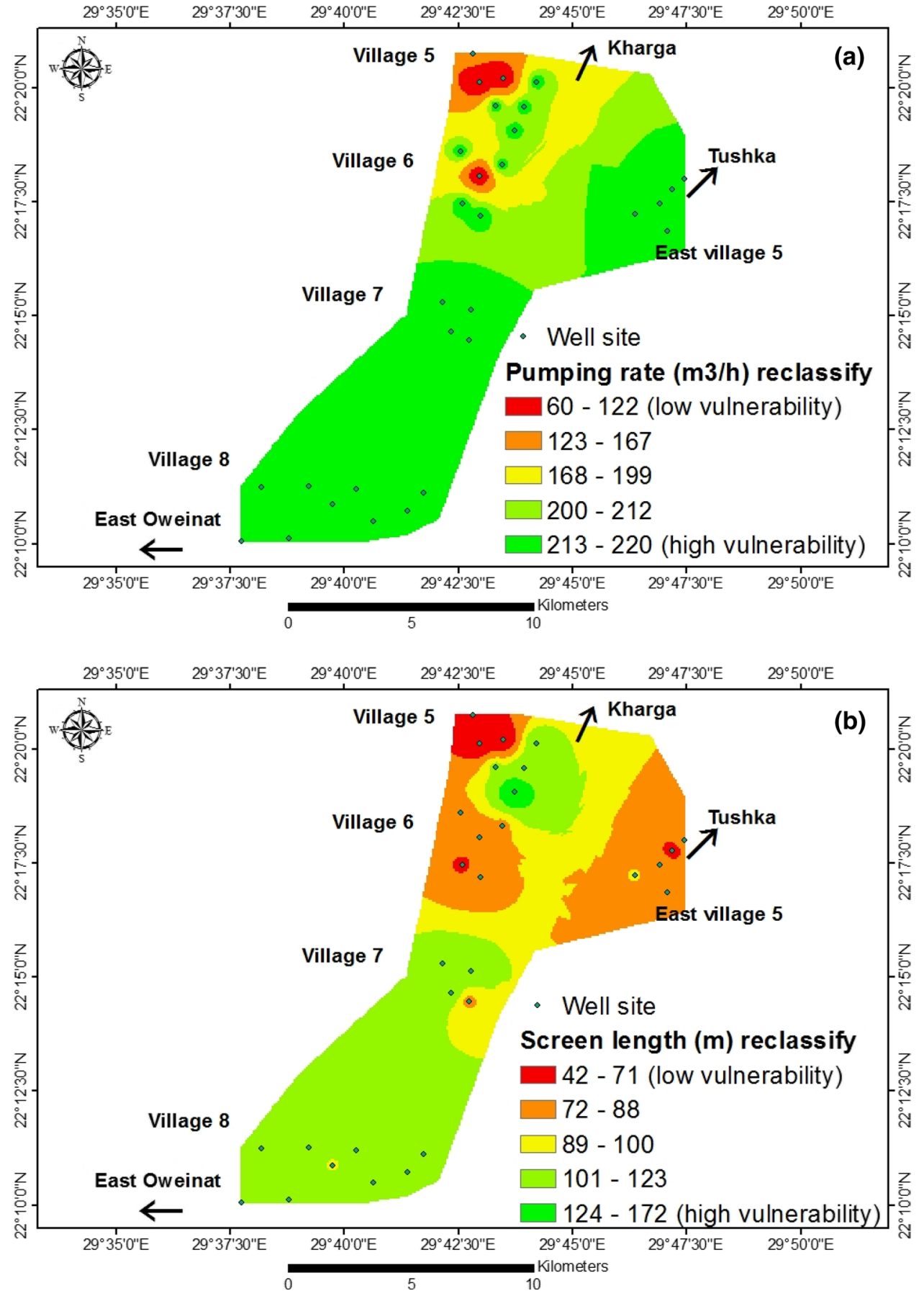

respectively (Table 4 ). The latter sum $64 \%$ of investigated area is currently degraded with respect to aquifer quality, which needs new watering techniques. Darb El Arbaein represents a new investment area, which should be free from anthropogenic influences now and in future. The application of certain crops (preferred low water consumption), sowing technology, fertilizers (quality and amount), pesticides, and best geological and hydrogeological conditions (hydrogeologist consultant), is specified to maintain and improve the aquifer and crops products. The high vulnerability level covers $10.35 \%$ of the investigated area, it is distinguished by the highest total dissolved solids (TDS 1214-1318 ppm, Fig. 11a). Although the TDS concentration is less than the irrigation guidelines limits, but the TDS concentration of the original groundwater is less than $200 \mathrm{ppm}$ and turned to the current values by pumping and irrigation system. The aim is to reduce the methods led to increase in groundwater and soil salinity over time and take care of this place so that groundwater irrigation is sustainable and efficient. The preferred invested areas located in the northeast rather 
Fig. 16 Groundwater vulnerability map

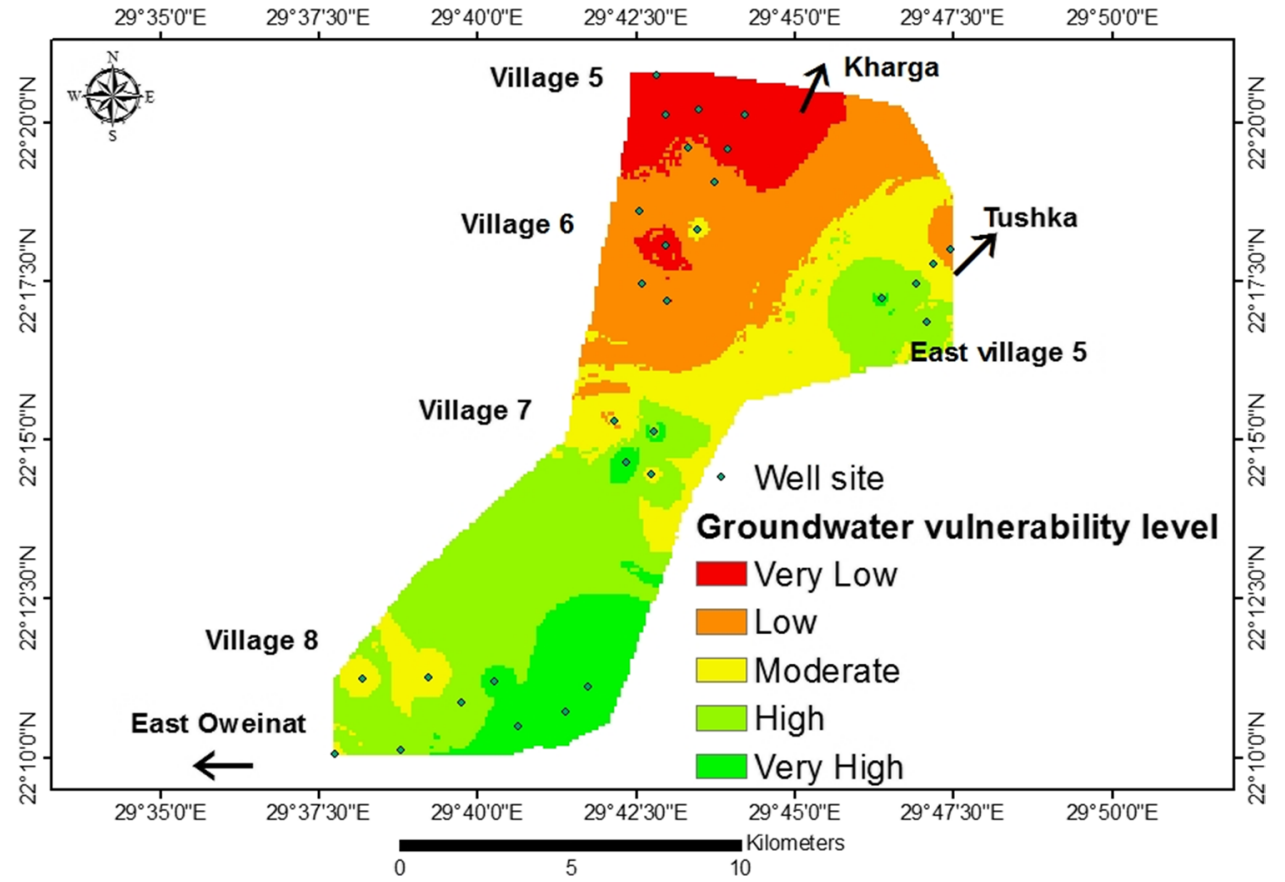

and barren lands, it is because vegetation or forests reflect higher reflectance in near IR region $(0.76-0.90 \mu \mathrm{m})$ and strong absorption in red region $(0.63-0.69 \mu \mathrm{m})$. The ratio determines the vegetation covers distribution (Fig. 17a).

\section{Composite bands 7, 4, and 1}

The composites give bright green for vegetation as shown in Fig. 17b, which match with vegetation areas constructed by band 4/band 3 Fig. 17b. Most of the drilled wells coincide with high vegetation covers (Fig. 17b).

\section{Band 3/band 4}

The ratio determines barren lands and urban area as shown in Fig. 17c.

\section{Summary and conclusions}

The multi-criteria establishment by GIS software was proved to construct aquifer vulnerability map for lithogenic and anthropogenic sources. It helps to manage and protect the Nubian sandstone aquifer. The continuous pumping and low aquifer recharge resulted in dropping in potentiometric surfaces and induced the salts into the Nubian sandstone aquifer systems. The hydraulic conductivity of the aquifer not exceeds $11 \mathrm{~m} / \mathrm{d}$, which reflect the fine sediments included within the sandstone. The hydrogeological characteristics of the aquifer are low to moderate, it should be accompanied by good management for pumping or otherwise the aquifer band 4 is the near-infrared band. The ratio promotes forests 
Fig. 17 Band ratios in southern Darb El Arbaein
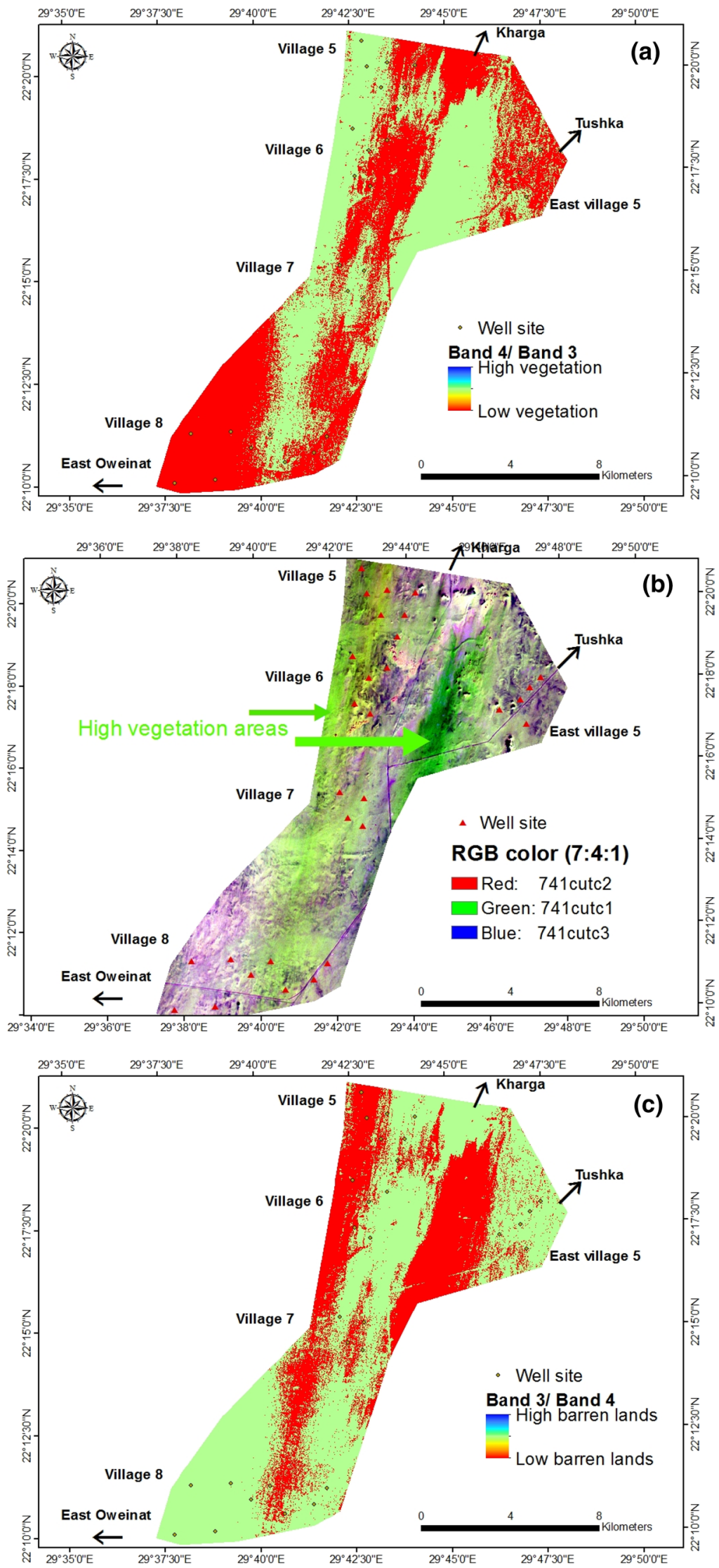
will degrade. Therefore, the aquifer vulnerability map was very important for the officials. This dissertation prepares this aquifer vulnerability map to match the hydrogeological and hydrogeochemical parameters. The resulting vulnerability map represents sustainable development for this new investment area. Ten stratified beds inputted into GIS model to construct the aquifer vulnerability model. The constructed map ranged from very low to very high in terms of their vulnerability to groundwater degradation. The low to very low vulnerability levels represent $36.12 \%\left(52.18 \mathrm{~km}^{2}\right.$ area) of the total study area $\left(144.5 \mathrm{~km}^{2}\right)$, they preferred to be best promising areas. Moderate to very high vulnerability levels contain $63.9 \%\left(92.3 \mathrm{~km}^{2}\right)$ of the study area. In spite of the highest TDS concentration is lower than $2000 \mathrm{ppm}$ (irrigation guideline), the groundwater originally was lower than $200 \mathrm{ppm}$ (River Nile) and degraded with time. The continuous increase in TDS concentration and piezometric drop causes soil and groundwater deterioration.

Funding No funding was received for conducting this study.

\section{Declarations}

Conflicts of interest The authors have no conflicts of interest to declare that are relevant to the content of this article.

Open Access This article is licensed under a Creative Commons Attribution 4.0 International License, which permits use, sharing, adaptation, distribution and reproduction in any medium or format, as long as you give appropriate credit to the original author(s) and the source, provide a link to the Creative Commons licence, and indicate if changes were made. The images or other third party material in this article are included in the article's Creative Commons licence, unless indicated otherwise in a credit line to the material. If material is not included in the article's Creative Commons licence and your intended use is not permitted by statutory regulation or exceeds the permitted use, you will need to obtain permission directly from the copyright holder. To view a copy of this licence, visit http://creativecommons.org/licenses/by/4.0/.

\section{References}

Abdel El Rahman (2003). Hydrogeological aspects of sandstone aquifer in Darb El Arbaein area, south Western Desert, Egypt. Ms. Sci. Cairo University

Adamat R, Foster I, Baban S (2003) Groundwater vulnerability and risk mapping for the Basaltic aquifer of the Azraq basin of Jordan using GIS, remote sensing and DRASTIC. Appl Geogr 23:303-324

Aggour TA, El Abd E (2009) New lights on the hydrogeology of Darb El Arbaein Area. West Desert Egypt Sedimentol Egypt 17:167-184

Aller L, Bennett T, Lehr JH, Pretty RJ, Hackett G (1987) DRASTIC: A standardized system for evaluating groundwater pollution Potential using hydrogeologic setting. U.S. EPA, RobertS. Kerr Environmental Research Laboratory, Ada, p622 (EPARep (035/287/600)

Ambroggi R (1966) Water under the Sahara. Sci Am 5:214-215
Ayers RS, Westcot DW (1985) Water quality for agriculture, FAO irrigation and drainage: Paperno. 29,Rev.10.U.N. Food and Agriculture Organization, Rome

Babiker IS, Mohamed MA, Hiyama T, Kato K (2005) AGIS-based DRASTIC model for assessing aquifer vulnerability in Kakamigahara Heights, GifuPrefecture, Central Japan. Sci Tot Environ 345(1-3):127-140

Barseem M (2016) Groundwater exploration by using geophysical techniques in the area between Gable Aabu Byan El Qibli and El Tamaneen village, Darb El Arbian, Western Desert, Egypt. Egy J Appl Geophys 15(2):1-23

Bierschenk W (1964). Determining well efficiency by multiple step drawdown test. Publication 64. International Association of Scientific Hydrology.

Brady NC, Weil RR (2002) The nature and properties of soils. Prentice Hall, Englewood Cliffs, NJ

Burkart MR, Kolpin DW, James DE (1999) Assessing groundwater vulnerability to agrichemical contamination in the Midwest US. Water Sci Tech 39(3):103-112

Ezzat M, Abu A (1974) Exploration of groundwater in El Wadi El Gedid project area (New valley), part II, Hydrogeological conditions. Dakhla-Kharaga area; Ministry of agriculture and land Reclamation, Cairo

Fathy R, Hefnawy M, Abdel HA (2001) Contributions to the hydrogeology aspects of the groundwater aquifer in southern part of Darb El Arbaein area, southern portion of Western Desert, Egypt. Al Azhar Bull Sci 12(2):175-194

Fathy RG, El Nagaty M, Atef A, El Gammal N (2002) Contribution to the hydrogeological and hydrochemical charateteristics of Nubian sandstone aquifer in Darb El Arbaein, southwestern Desert, Egypt. Al Azhar Bull Sci 13(2):69-100

Fred W, Besien T, Kolpin DW (2002) Groundwater vulnerability: interactions of chemical and site properties. Sci Total Environ 299(1):131-143

Continental Oil Company (CONOCO, 1989) Geologic map of Egypt scale 1:500 000

German Water Group (1977) Hydrogeological study of groundwater resources in the Kufra area; German Water Engineers, GB, p.5

Ghoubashi SY (2004) Comparative hydrological studies of the Nubia Sandstone aquifer system in East El-Oweinat and Bir El Shab areas, South Western Desert, Egypt. PhD Thesis, Al-Azhar University, Egypt

Hamza MH, Added A, Rodriguez R, Abdeljaoued S, Mammou B (2007) AGIS-based DRASTIC vulnerability and net recharge reassessment in an aquifer of a semi-arid region (Metline-Ras Jebel-Raf Raf aquifer, Northern Tunisia). J Environ Manag 84:12-19

Hendriks FL, Luger H, Kallenbach JH, Schroeder G (1984) Stratigraphic and sedimentlogical framework of the Kharga-Sinn ElKaddab strech (Western and Southern part of the Upper Nile Basin) Western Desert, Egypt. Berl Geowiss Abh 50:117-151

Issawi B (1971) Geology of Darb El Arbaein, western Desert. Egypt Ann G S E, Cairo 46:120

Jacob C (1946) Drawdown test to determine the effective radius of an artesian well. Trans Am Soc Civ Eng 112:1047-1070

Kimand YJ, Hamm S (1999) Assessment of the potential for groundwater contamination using the DRASTIC/EGIS technique, Cheongju area, South Korea. Hydrogeol J 7(2):227-235

Knox RC, Sabatini DA, Canter LW (1993) Subsurface transport and fate processes. Lewis publishers, USA, Boca Raton, FL, p 430

Korany E, Fathy G, El Nagaty M (2002) Contributions to the hydrogeology of Nubian sandstone aquifer in the middle part of Darb El Arbaein, southwestern Desert, Egypt. J Sedimentology Soc 10:119-143

Leone A, Ripa MN, Uricchio V, Deak J, Vargay Z (2009) Vulnerability and risk valuation of agricultural nitrogen pollutionfor 
Hungary's main aquifer using DRASTIC and GLEAMS models. J Environ Manag 90:2969-2978

Margat J (1968) Vulnerabilite desnappes d'eau souterraineala pollution. Basede lacartographie, Doc. BRGM, 68 SGL 198 HYD. Orlean, France.

Mondal NC, Adike S, Singh VS, Ahmed S, Jayakumar KV (2017) Determining shallow aquifer vulnerability by the DRASTIC model and hydrochemistry in granitic terrain, southern India. J Earth Syst Sci 126:89

Nasri N, Chebil M, Guellouz L, Bouhlila R, Maslouhi A, Ibnoussina M (2015) Modelling nonpoint source pollution by nitrate of soil in the Mateur plain, northeast of Tunisia. Arab Jour Geosci 8:1057-1075

Prasad K, Shukla JP (2014) Assessment of groundwater vulnerability using GIS-based DRASTIC technology for the basaltic aquifer of Burhner watershed, Mohgaon block, Mandla (India). Curr Sci 107(10):1649-1656

Sahu PC, Nandi D (2015) Evaluation of ground water pollution potential using drastic model: a case study in Berhampur City, Orissa. Int J Geol Earth Environ Sci 5(3):55-61

Shata A (1982) Hydrogeology of the great Nubian sandstone basin . Quat J Eng 15:127-133 (London)
Shata A, Knetsch G, El Shazly M (1962) The geology, origin, and age of the groundwater supplies in some desert areas of UAR: Bull Inst Desert. El Matariya, and Cairo 12(2):61-124

General Authority for Rehabilitation Projects and Agricultural Development (GARPAD 98/2000) Lithologic logs and geophysical logs of water wells, Darb El Arbaein area, southwestern Desert, Egypt

Thirumalaivasan D, Karmegam M, Venugopal K (2003) AHP DRASTIC: software for specific aquifer vulnerability assessment using DRASTIC model and GIS. Environ Model Softw 18:645-656

USEPA (1987) A review of methods for assessing aquifer sensitivity and groundwater vulnerability to pesticide contamination: report no. EPA813-R-93-002.United States Environmental Protection Agency, Washington, DC

Yeh PJF, Swenson SC, Famiglietti JS, Rodell M (2006) Remote sensing of groundwater storage changes in Illinois using the Gravity Recovery and Climate Experiment (GRACE). Water Resour Res 42(12):W12203

Zhou J, Li G, Liu F, Wang Y, Guo X (2010) DRASTIC model and its application in assessing groundwater vulnerability in arid area: a case study of pore phreatic water in Tarim Basin, Xinjiang Northwest China. Environ Earth Sci 60(5):1055-1063 